\title{
Screening-level microbial risk assessment of acute gastrointestinal illness attributable to wastewater treatment systems in Nunavut, Canada
}

Daley, Kiley; Jamieson, Rob; Rainham, Daniel; Hansen, Lisbeth Truelstrup; Harper, Sherilee L.

\section{Published in:}

Science of the Total Environment

Link to article, DOI:

10.1016/j.scitotenv.2018.11.408

Publication date:

2019

Document Version

Peer reviewed version

Link back to DTU Orbit

Citation (APA):

Daley, K., Jamieson, R., Rainham, D., Hansen, L. T., \& Harper, S. L. (2019). Screening-level microbial risk assessment of acute gastrointestinal illness attributable to wastewater treatment systems in Nunavut, Canada. Science of the Total Environment, 657, 1253-1264. https://doi.org/10.1016/j.scitotenv.2018.11.408

\section{General rights}

Copyright and moral rights for the publications made accessible in the public portal are retained by the authors and/or other copyright owners and it is a condition of accessing publications that users recognise and abide by the legal requirements associated with these rights.

- Users may download and print one copy of any publication from the public portal for the purpose of private study or research.

- You may not further distribute the material or use it for any profit-making activity or commercial gain

- You may freely distribute the URL identifying the publication in the public portal 


\section{Title}

Screening-level microbial risk assessment of acute gastrointestinal illness attributable to wastewater treatment systems in Nunavut, Canada

\section{Authorship}

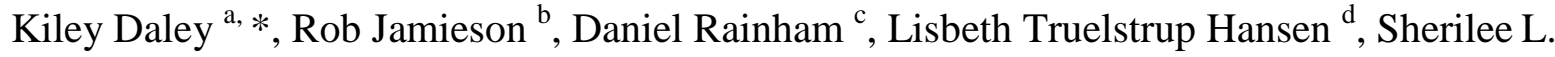
Harper $^{\mathrm{e}}$

${ }^{a}$ Centre for Water Resources Studies, Dalhousie University, 1360 Barrington Street, Halifax, Nova Scotia B3H 4R2, Canada, kiley.daley@dal.ca

${ }^{\mathrm{b}}$ Centre for Water Resources Studies, Dalhousie University, 1360 Barrington Street, Halifax, Nova Scotia B3H 4R2, Canada, jamiesrc@dal.ca

${ }^{\mathrm{c}}$ Healthy Populations Institute, Dalhousie University, 1318 Robie Street, Halifax, Nova Scotia B3H 4R2, Canada, daniel.rainham@dal.ca

${ }^{d}$ National Food Institute, Technical University of Denmark, DK-2800 Kongens Lyngby, Denmark, litr@food.dtu.dk

${ }^{\text {e }}$ School of Public Health, University of Alberta, $1140587^{\text {th }}$ Avenue, Edmonton, Alberta T6G 1C9, Canada, sherilee.harper@ualberta.ca

${ }^{*}$ Corresponding author 


\section{Abstract}

6 Most arctic communities use primary wastewater treatment systems that are capable of only low levels

7 of pathogen removal. Effluent that potentially contains fecally-derived microorganisms is released into

8 wetlands and marine waters that may simultaneously serve as recreation or food harvesting locations

9 for local populations. The purpose of this study is to provide the first estimates of acute gastrointestinal

10 illness (AGI) attributable to wastewater treatment systems in Arctic Canada. A screening-level, point

11 estimate quantitative microbial risk assessment (QMRA) model was developed to evaluate worst-case

12 scenarios across an array of exposure pathways in five case study locations. A high annual AGI

13 incidence rate of 5.01 cases per person is estimated in Pangnirtung, where a mechanical treatment plant

14 discharges directly to marine waters, with all cases occurring during low tide conditions. The

15 probability of AGI per person per single exposure event during this period ranges between 0.10 (shore

16 recreation) and 0.63 (shellfish consumption). A moderate incidence rate of 1.16 episodes of AGI per

17 person is estimated in Naujaat, where a treatment system consisting of a stabilization pond and tundra

18 wetland is used, with the majority of cases (87\%) occurring during spring. The pathway with the

19 highest individual probability of AGI per single exposure event is wetland travel at 0.60 . All of the

20 remaining risk probabilities per single exposure are less than 0.01 . The AGI incidence rates estimated

21 for the other three case study location are low $(\leq 0.13)$. These findings suggest that wastewater

22 treatment sites may be contributing to elevated rates of AGI in some arctic Canadian communities. The

23 absolute risk values, however, should be weighed with caution based on the exploratory nature of this 
study design. These results can be used to inform future risk assessment and epidemiological research as well as support public health and sanitation infrastructure decisions in the region.

\section{Keywords}

Indigenous health; Arctic; Rural and remote health; Quantitative Microbial Risk Assessment (QMRA);

Water, Sanitation, and Hygiene (WASH)

\section{Introduction}

Communities in the Arctic employ basic wastewater (sewage) treatment systems, which maybe contributing to elevated rate of infectious disease in the region (Harper et al., 2015; Hayward et al., 2014; Ragush et al., 2015; Yates et al., 2012). In many ways these economical treatment systems, which make use of natural environmental processes, are effective and well-suited for the small population sizes and extreme climate of the Arctic (Heinke et al. 1991; ITK and Johnson 2008). A limitation, however, is that they are capable of only primary treatment and low levels of pathogen removal (Hayward et al., 2014; Huang et al., 2017; Ragush et al., 2015; Yates et al., 2012). As a result, partially treated effluent potentially containing fecally derived microorganisms is released into wetlands and marine waters near communities (Huang et al., 2017; Krumhansl et al., 2015). The predominantly Indigenous populations in Arctic Canada have strong connections to their immediate physical environment; as such, the natural areas that are being used for passive wastewater treatment may simultaneously serve as recreation or food harvesting locations (Nilsson et al., 2013). Within these mixed ecological systems, people may unknowingly be exposed to wastewater pathogens, either by 
direct contact or indirectly through handling of contaminated wild food (Dorevitch et al., 2012; Holeton et al., 2011).

There are several microbial pathogens of human health concern which may be present in domestic wastewater (Bitton, 2005). Some of these have a very low infectious dose, meaning that they can lead to acute gastrointestinal illness (AGI) and other human diseases even after exposure to low concentrations (Leclerc et al., 2002). Within Inuit Nunangat, the distinct Inuit region of Arctic Canada, the enteric illness burden is believed to be significantly higher than in southern parts of the country (Parkinson et al., 2014). A study of self-reported AGI in Inuit communities estimated a range of 2.9 to 3.9 annual cases per person; a stark contrast to a national estimate of 0.6 annual cases per person (Harper et al., 2015; Thomas et al., 2013) and higher than average estimates from developing countries (0.8-1.3) as well (Mathers et al., 2002; WHO, 2006). Furthermore, socioeconomic challenges in some remote Arctic communities, such as suboptimal housing, nutrition, and health care access may exacerbate the seriousness and longer term implications of AGI (Hennessy and Bressler, 2016; Yansouni et al., 2016). The degree of enteric illness attributable to wastewater contamination in the Arctic is currently unknown. Studies of pathogens present in fecal samples collected from cases of AGI have yet to be linked with wastewater exposure (Goldfarb et al., 2013; Iqbal et al., 2015; McKeown et al., 1999; Messier et al., 2012; Pardhan-Ali et al., 2012a, 2012b; Thivierge et al., 2016). However, environmental contamination from wastewater treatment sites remains a potential risk factor and ongoing concern among communities and public health officials in the region (Daley et al., 2015; Goldfarb et al., 2013; Hastings et al., 2014; Pardhan-Ali et al., 2013).

The limited knowledge of possible human health impacts attributable to wastewater treatment operations in the Arctic is partially due to the complexity of the setting. Defining the exposure 
71 pathways and characterizing health risk in a natural system is difficult due to the conflux of human and

72 environment interactions, none of which are likely to follow a linear relationship or have been

73 elucidated with full field data sets (Haas et al., 2014). Resource-intensive epidemiological studies of

74 multiple exposure pathways, without clear associations between microbial hazard sources and health

75 outcomes are not well-suited for this type of problem. A broader assessment, which considers the

76 whole ecological system and is flexible enough to include an array of microorganisms and exposures, is

77 better suited to model conditions and estimate the level of risk (Boehm et al., 2009; Dunn et al., 2014;

78 Waltner-Toews et al., 2003).

79

80 Quantitative microbial risk assessment (QMRA) has emerged as a practical approach for evaluating

81 health risks in complex ecological systems (Haas et al., 2014). The disease burden attributable to

82 microbial pathogens in the environment can be estimated based on information about their

83 concentration and distribution or that of suitable surrogates, i.e., usually indicator organisms (Haas et

84 al., 2014; USEPA, 2012). It is particularly useful for assessing risk at low levels of exposure (Haas et

85 al., 2014). Through four stages (hazard identification, exposure assessment, dose-response analysis,

86 risk characterization), data from a variety of sources, including field studies, models, and literature, are

87 integrated to quantify the microbial risks attributed with defined exposure scenarios. A range of

88 computationally-demanding and detailed analysis is possible - from point estimate risk

89 characterizations to stochastic models incorporating Monte Carlo simulation - depending on

90 availability of data and scope of the problem. This design flexibility makes QMRA a useful tool to

91 estimate effects where direct measurements of microbial pathogens at the point of exposure are not

92 available or feasible (Haas et al., 2014; Howard et al., 2006). Simplified QMRA approaches have been

93 adapted for use in some developing regions with limited data (Ferrer et al., 2012; Howard et al., 2006;

94 Hunter et al., 2009; Yapo et al., 2014). QMRA has also been used in other contexts where populations 
may be unknowingly exposed to wastewater effluent through food harvesting or recreational activities (Fuhrimann et al., 2017; 2016). These applications are promising for the use of QMRA in addressing similar public health challenges in remote, arctic communities.

Considering the basic treatment systems and high rates of AGI in the Arctic, the objective of this study is to provide the first estimates of microbial health risks attributable to wastewater-borne pathogens in Inuit Nunangat and other Arctic Canadian communities. A conceptual model, supported by a literature review, was first developed to serve as a directional guide for the risk assessment (Daley et al., 2017). A simplified, point estimate QMRA model was then designed to allow a broad range of potential exposure pathways to be evaluated and to discern those that pose high levels of risk and warrant further attention.

\section{Methods}

\subsection{Ethical considerations}

The study protocol was reviewed and approved by the Dalhousie University Research Ethics Board (reference number 2013-3021). This study is registered with the Nunavut Research Institute.

\subsection{QMRA scope and design}

Given the exploratory nature of this research and limited local data, the risk assessment was designed as a screening level, point estimate model. This type of QMRA is very useful in comparing and ranking scenarios prior to proceeding with a more complex stochastic assessment of those presenting the highest risk (Sales-Ortells and Medema, 2014; USEPA, 2012; WHO, 2016). All model inputs were based on site-specific data, where available, or existing literature. Conservative, but plausible, values were used in order to represent point estimates of maximum reasonable exposure. 


\section{$120 \quad 2.3$ Hazard identification}

121 The microbial hazard source was associated with partially-treated wastewater effluent being released

122 from treatment sites. Most communities in Arctic Canada use passive treatment systems comprised of

123 wastewater stabilization ponds (WSPs) that are referred to locally as lagoons and wetlands. The

124 wastewater treatment site is typically located on the perimeter of the main habitation area. Effluent is

125 discharged into the WSP where it is stored and remains frozen for the seven to eight month duration of

126 the arctic winter. WSPs across the region vary in terms of initial design - from unaltered existing

127 shallow depressions to engineered ponds with polyethylene liners and granular berms to prevent

128 unplanned seepage (Ragush et al., 2015; Schmidt et al., 2016). The WSPs also differ regarding state of

129 repair and operational procedures. During the spring and summer in some communities, the effluent

130 either seeps or is manually decanted into natural tundra wetlands, where further passive treatment

131 occurs (Hayward et al., 2014; Yates et al., 2012). The effluent ultimately enters a marine receiving

132 water body within or near community boundaries. In a few communities, wastewater is treated using

133 primary mechanical plants, rather than WSPs, and is discharged directly to a marine receiving

134 environment (Krumhansl et al., 2015). These mechanical systems can be prone to malfunction, often

135 relating to cold temperatures, and can be offline for extended time periods as the remote locations make

136 access to replacement parts and repair challenging (Johnson et al., 2014). At present, most systems in

137 Arctic Canada are classified as primary treatment with no effluent disinfection, meaning low levels of

138 pathogen removal (Huang et al., 2017).

140 Six pathogenic agents were included in the assessment: three bacteria (Escherichia coli, Salmonella

141 spp., and Campylobacter jejuni); one virus (rotavirus); and two protozoa (Giardia lamblia, and

142 Cryptosporidium parvum). All six agents are commonly present in partially-treated wastewater effluent 
143 and transmissible via faecal-oral routes (i.e., direct accidental ingestion of water, hand-to-mouth

144 exchange following contact with contaminated water, or ingestion of contaminated food). The

145 prevalence and emergence of pathogenic infections in Arctic Canadian populations were considered

146 during the selection of microorganisms (Goldfarb et al., 2013; Iqbal et al., 2015; Pardhan-Ali et al.,

147 2012b; Thivierge et al., 2016; Yansouni et al., 2016). As a simplification within the entire assessment,

148 we refer to the pathogenic strains known to be associated with AGI.

149

\section{$150 \quad 2.4$ Exposure assessment}

$151 \quad 2.4 .1$ Case study locations

152 Based on sufficient water quality data having been collected in their receiving environments, five

153 Nunavut communities were selected as QMRA case study locations: Iqaluit, Pangnirtung, Pond Inlet,

154 Sanikiluaq, and Naujaat (Figure 1). These sites represent examples of all the major treatment type and 155 receiving environment combinations found in the Territory of Nunavut. 


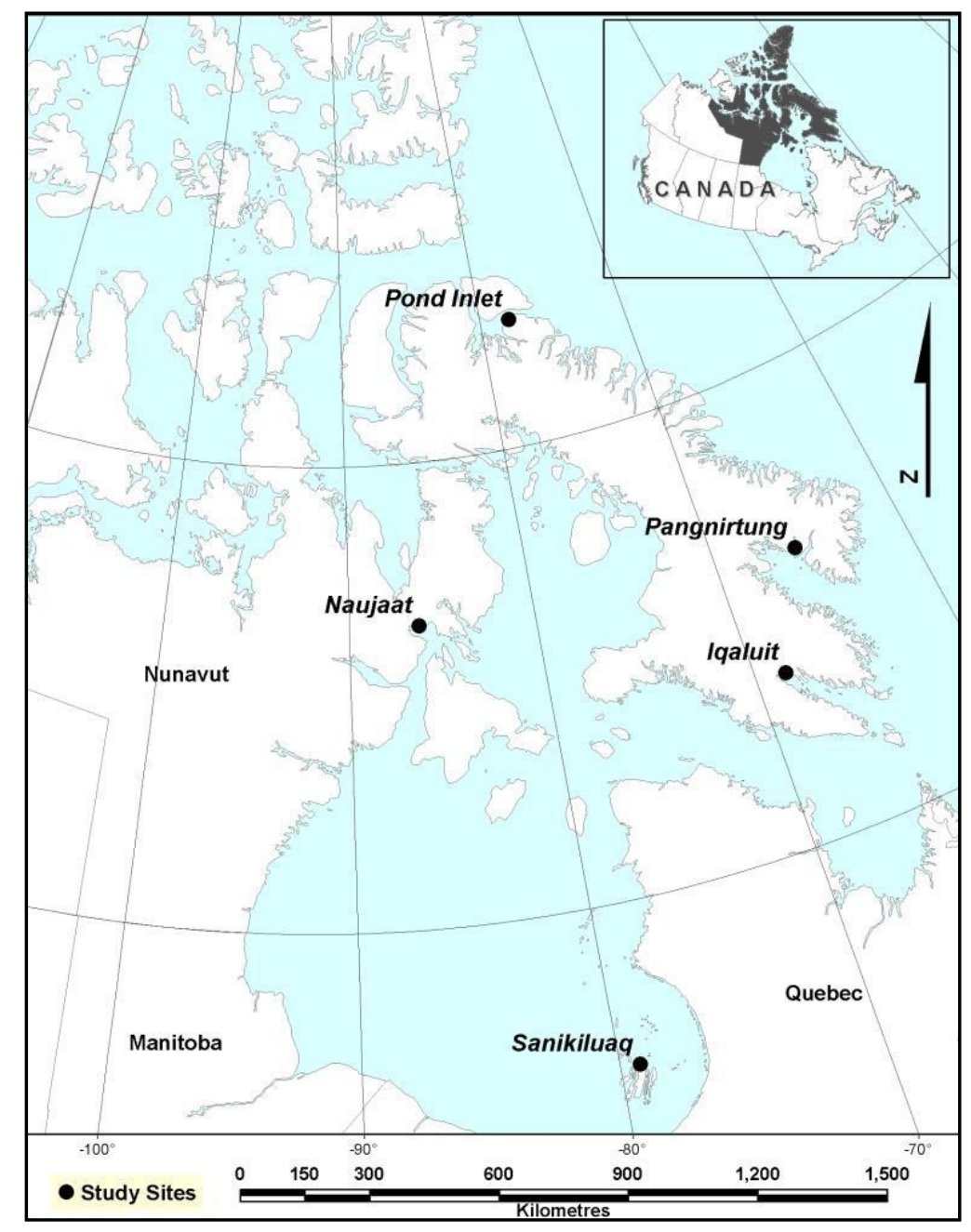

157 Figure 1. Map of five case study locations in the territory of Nunavut, Canada (lqaluit, Naujaat, Pangnirtung,

158 Pond Inlet, and Sanikiluq).

159

160 Community locations, populations, annual volume of wastewater, treatment system, effluent discharge

161 schedule, annual volume of wastewater $\left(\mathrm{m}^{-3}\right)$, effluent $E$. coli concentrations at discharge reported as

162 most probable number (MPN) of coliform per $100 \mathrm{ml}$ of water, and receiving environment

163 characteristics including maximum tidal range (m) are presented in Table 1.

164 
Table 1 Characteristics of the five case study locations included in the quantitative microbial risk assessment (QMRA) to estimate the burden of acute gastrointestinal illness (AGI) attributable to wastewater treatment in Arctic Canada.

\begin{tabular}{|c|c|c|c|c|c|c|}
\hline $\begin{array}{l}\text { Community } \\
\text { and location }\end{array}$ & $\begin{array}{l}\text { Population } \\
\text { size }\end{array}$ & $\begin{array}{l}\text { Treatment } \\
\text { type }\end{array}$ & $\begin{array}{l}\text { Discharge } \\
\text { method } \\
\text { and timing }\end{array}$ & $\begin{array}{l}\text { Wastewater } \\
\text { volume } \\
\left(\mathrm{m}^{3} / \text { year) }\right.\end{array}$ & $\begin{array}{l}\text { E. coli } \\
\text { concentration } \\
\text { at initial } \\
\text { discharge } \\
\text { (MPN/100 mL) }\end{array}$ & $\begin{array}{l}\text { Receiving } \\
\text { environment } \\
\text { and maximum } \\
\text { tidal range }(\mathrm{m})\end{array}$ \\
\hline $\begin{array}{l}\text { Iqaluit } \\
63^{\circ} 44^{\prime} 40^{\prime \prime} \mathrm{N}, \\
68^{\circ} 31^{\prime} 01^{\prime \prime} \mathrm{W}\end{array}$ & 7740 & $\begin{array}{l}\text { Mechanical } \\
\text { treatment } \\
\text { (bulk solids } \\
\text { removal) }\end{array}$ & $\begin{array}{l}\text { Continuous, } \\
\text { year round }\end{array}$ & 867,167 & $1.12 \times 10^{7}$ & $\begin{array}{l}\text { Inlet/small bay, } \\
11.0\end{array}$ \\
\hline $\begin{array}{l}\text { Pangnirtung } \\
66^{\circ} 08^{\prime} 47^{\prime \prime} \mathrm{N}, \\
65^{\circ} 42^{\prime} 04^{\prime \prime} \mathrm{W}\end{array}$ & 1481 & $\begin{array}{l}\text { Mechanical } \\
\text { treatment } \\
\text { (activated } \\
\text { sludge) }\end{array}$ & $\begin{array}{l}\text { Continuous, } \\
\text { year round }\end{array}$ & 49,751 & $1.23 \times 10^{5}$ & $\begin{array}{l}\text { Narrow fiord, } \\
6.9\end{array}$ \\
\hline $\begin{array}{l}\text { Pond Inlet } \\
72^{\circ} 42^{\prime} 00^{\prime \prime} \mathrm{N}, \\
77^{\circ} 57^{\prime} 30^{\prime \prime} \mathrm{W}\end{array}$ & 1617 & $\begin{array}{l}\text { Stabilization } \\
\text { pond with no } \\
\text { wetland }\end{array}$ & $\begin{array}{l}\text { Controlled } \\
\text { decant, 2-3 } \\
\text { weeks in late } \\
\text { summer }\end{array}$ & 41,046 & $4.40 \times 10^{5}$ & $\begin{array}{l}\text { Open marine, } \\
2.5\end{array}$ \\
\hline $\begin{array}{l}\text { Sanikiluaq } \\
56^{\circ} 32^{\prime} 34^{\prime \prime} \mathrm{N}, \\
79^{\circ} 13^{\prime} 30^{\prime \prime} \mathrm{W}\end{array}$ & 882 & $\begin{array}{l}\text { Stabilization } \\
\text { pond and } \\
\text { wetland }\end{array}$ & $\begin{array}{l}\text { Continuous } \\
\text { uncontrolled } \\
\text { seepage, 12-15 } \\
\text { weeks (from } \\
\text { spring freshet } \\
\text { until winter } \\
\text { freeze) }\end{array}$ & 32,120 & $\begin{array}{l}6.00 \times 10^{4} \\
\text { (spring), } \\
2.30 \times 10^{4} \\
\text { (summer) }\end{array}$ & $\begin{array}{l}\text { Wetland into } \\
\text { open marine, } \\
1.2\end{array}$ \\
\hline $\begin{array}{l}\text { Naujaat } \\
66^{\circ} 31^{\prime} 19^{\prime \prime} \mathrm{N}, \\
86^{\circ} 14^{\prime} 16^{\prime \prime} \mathrm{W}\end{array}$ & 1082 & $\begin{array}{l}\text { Stabilization } \\
\text { pond and } \\
\text { wetland }\end{array}$ & $\begin{array}{l}\text { Continuous } \\
\text { uncontrolled } \\
\text { seepage, 12-15 } \\
\text { weeks (from } \\
\text { spring freshet } \\
\text { until winter } \\
\text { freeze) }\end{array}$ & 35,430 & $\begin{array}{l}1.73 \times 10^{6} \\
\text { (spring), } \\
1.10 \times 10^{6} \\
\text { (summer) }\end{array}$ & $\begin{array}{l}\text { Wetland into } \\
\text { open marine, } \\
3.9\end{array}$ \\
\hline
\end{tabular}


171 Aside from the physical and natural characteristics of the wastewater treatment areas, the case study

172 locations also vary regarding the types of interactions taking place at the human-environment interface.

173 Understanding these interactions and carefully delineating the exposure pathways in this previously

174 uninvestigated setting was an important step in the assessment. Emphasis was placed on incorporating

175 community-grounded information into the model in order to accurately depict potential exposure

176 scenarios (Barber and Jackson, 2015), using participatory epidemiology techniques. Between 2013 and

1772016 , a total of 11 data collection visits were made to the case study locations by members of the

178 research team. Each community was visited at least twice, with each trip lasting one to three weeks.

179 Key informant meetings were held, which included questionnaires and site-mapping in order to gather

180 activity pattern data about the local population's interactions with the land and water surrounding

181 wastewater treatment sites and their awareness of potential hazards. The key informants included

182 public health officials, municipal wastewater operators, wildlife and environmental conservation

183 officers, and subsistence hunters and fishers. A total of 42 meetings with key informants were

184 conducted, with each meeting lasting from 30 to 60 minutes. Key informant data were used to identify

185 the most likely wastewater-associated exposure pathways in each case study location and to set model

186 parameters for event locations, timing, durations, frequency, and exposure group sizes. Community

187 presentations and displays were also organized, where approximately 100 additional members of the

188 public provided general comments regarding human activity surrounding the treatment areas. Site

189 assessments of each treatment area were conducted alongside engineers and local partners to situate

190 human-environment interaction data. Ingestion rates for each exposure were sourced from literature.

191 Corrective factors were used to adjust standard literature-based exposure factors to the local context.

192 The corroboration of exposure factors from literature-to-local has been demonstrated in previous

193 QMRA applications (Barker et al., 2014; Fuhrimann et al., 2016). 
195 Six activities were selected as the most likely pathways of human exposure to wastewater hazards:

196 shoreline recreation; small craft boating; netfishing; shellfish harvesting; shellfish consumption; and

197 wetland travel. Descriptions of each pathway are provided below and a full summary of the human

198 activity parameters used in the QMRA model are presented in Table 2. The parameters include:

199 distance (location where the human exposure event occurs as measured in metres from the effluent 200 release point); frequency (number of exposure events per year); exposure group (number of individual 201 people exposed per event); and ingestion (amount of media ingested per individual per exposure event). 202 In all but the shellfish consumption scenario, the modelled transmission route is accidental ingestion of 203 contaminated water. In the shellfish consumption scenario, the transmission route is ingestion of 204 contaminated tissue. Community data showed that people do not source drinking water downstream 205 from any of the wastewater treatment sites. Consumption of contaminated finfish (non-shellfish), 206 marine mammals, and wild game were also excluded as transmission routes in this screening-level 207 assessment as dose-response data for these mediums as a secondary source of microbial contamination 208 is limited (CAMRA, 2015). The accidental ingestion rates for shoreline recreation, small craft boating, 209 and netfishing were adapted from values characterizing three classes of water recreation exposure 210 (Dorevitch et al., 2011; McBride et al., 2013). The low contact accidental ingestion rate is an average 211 of $3.8 \mathrm{~mL} /$ hour and is applicable to activities such as fishing and wading. A middle contact average rate 212 of $5.8 \mathrm{~mL} /$ hour is recommended for canoeing or kayaking with occasional capsizing and the high 213 contact average rate of $10.0 \mathrm{~mL} /$ hour pertains to swimming. Three times the average value is 214 recommended for use as a conservative estimate (Dorevitch et al., 2011; McBride et al., 2013). 215 Accidental ingestion rates for the wetland travel and shellfish harvesting exposure pathways were 216 drawn from assessments of agricultural and aquacultural harvest work in areas where wastewater 217 irrigation is practiced (Fuhrimann et al., 2016, 2017; WHO, 2006). These studies included assessment 
of harvesting crops such as rice grown in marshy areas - similar to the tundra wetland sites - and suggest $50.0 \mathrm{~mL} /$ day as a conservative accidental ingestion rate.

Shoreline recreation: All five case study locations are coastal communities and as such the shoreline is a focal point of human activity. Houses are often situated close to the water and the nearby shore is 223 used to store boats, vehicles, and equipment. It also serves as a public walking trail and children's play area. It is plausible that children may splash and wade into the edge of the water, though swimming or 225 full submersion would be rare. Community shorelines are also common areas for rod fishing, which could include shallow wading and handling of wet fish and fishing equipment. Shoreline recreation was classified with a conservative, low-exposure contact rate and estimated event duration of two hours 228 resulting in an accidental ingestion of $22.8 \mathrm{~mL}$ per event (Dorevitch et al., 2011; McBride et al., 2013).

Small craft boating: The use of small watercraft near the community and wastewater marine receiving environments is common in all case study locations. Most popular are small, open-top boats fitted with outboard motors. Larger boats as well as kayaks are also seen. Accidental ingestion may occur through 233 fishing, spray created by motors or paddles, wading into the water from shore to launch the boat, or an occasional capsize. An ingestion rate of $34.8 \mathrm{~mL}$ per event was assumed based on the conservative, 235 mid-exposure contact rate classification and estimated event duration of two hours (Dorevitch et al., 2011; McBride et al., 2013).

238 Netfishing: Similar in many ways to the small craft boating scenario, netfishing was also designated a 239 mid-exposure contact rate (Dorevitch et al., 2011; McBride et al., 2013). A corrective factor of five 240 times the average rate was applied, however, leading to an accidental ingestion per exposure event of $24158.0 \mathrm{~mL}$. Reasoning for the corrective exposure factor is that netfishing entails reaching over the edge 
of the boat and into the water to set or retrieve equipment such as large nets, ropes, and buoys.

243 Furthermore, the nets remain suspended within the marine water for several hours or days, increasing

244 the potential for contamination. Our model assumed recreational, as opposed to commercial, netfishing

245 and therefore no use of specialized protective clothing or decontamination procedures.

247 Shellfish harvesting: The shellfish scenarios are applicable only to Iqaluit and Pangnirtung, and only 248 during low tide conditions, when several kilometres of fine grained sea bed are exposed. During this 249 time, people walk on the tidal flats and dig shellfish (mostly clams) from the sea bed using their hands 250 or a small trowel. Evidence has shown that fecal coliforms can become concentrated in mud and sand, 251 with the bottom sediment acting as a reservoir, and increase the risk of enteric illness (Ford, 2005; 252 Heaney et al., 2012). The accidental water ingestion rate for shellfish harvesting is $50.0 \mathrm{~mL}$ per day 253 (Fuhrimann et al., 2017; WHO, 2006).

Shellfish consumption: Exposure via consumption of contaminated shellfish was evaluated independently of accidental water ingestion depicted during the harvesting scenario. Pathogens can become concentrated within the digestive tissue of shellfish that obtain their nutrients by filtering large quantities of seawater (Bitton, 2005; Ford, 2005). The infectious agents are then potentially transmissible to humans who consume the shellfish raw or partially cooked. Most organisms that lead to infectious illness can be killed or inactivated through thorough cooking (Butt et al., 2004). The community data did, however, indicate a preference for raw or lightly cooked shellfish among some 262 residents. A reduction factor of 0.5 was assumed and applied to the concentration within the shellfish 263 tissue to account for the range of preparation methods. Another longstanding custom within Inuit 264 communities is the sharing of harvested food, referred to as country food, with family and community 265 members (Collings et al., 1998). To reflect this practice, it was assumed that each harvester shared 
266 collected shellfish with three other people. Thus, the exposure group size parameter used in the

267 shellfish harvesting scenario was multiplied by four. The shellfish consumption value per exposure 268 event of 75 grams was based on a standard seafood portion per serving with consideration given to 269 North American Indigenous populations (Health Canada, 2007; Moya, 2004).

271 Wetland travel: This scenario is only applicable to Sanikiluaq and Naujaat; the two case study locations 272 that incorporate tundra wetlands into the wastewater treatment system. Wetland travel includes 273 traversing the area by foot, all-terrain vehicle, or snowmobile (during the spring when there is still 274 snow within the wetland). Although it is well-known within communities that the stabilization pond is 275 a hazard, it may not be apparent that the wetland is also part of the wastewater treatment train as there 276 is typically little or no signage or fencing. People may enter or pass thru the wetland while small game 277 hunting, berry picking, or collecting geese eggs. The accidental ingestion rate for wetland travel is 50.0 278 mL per day (Fuhrimann et al., 2017; WHO, 2006).

Summary of human activity parameters per case study location, receiving environment conditions, and exposure pathway included in the quantitative microbial risk assessment (QMRA) model to estimate acute gastrointestinal illness (AGI) attributable to wastewater treatment systems in Arctic Canada.

\begin{tabular}{|c|c|c|c|c|c|c|c|c|c|c|}
\hline Case study location & \multicolumn{2}{|c|}{ Iqaluit } & \multicolumn{2}{|c|}{ Pangnirtung } & \multicolumn{2}{|c|}{ Pond Inlet } & \multicolumn{2}{|c|}{ Sanikiluaq } & \multicolumn{2}{|c|}{ Naujaat } \\
\hline $\begin{array}{l}\text { Receiving environment } \\
\text { conditions }\end{array}$ & $\begin{array}{l}\text { High } \\
\text { tide }\end{array}$ & $\begin{array}{l}\text { Low } \\
\text { tide }\end{array}$ & $\begin{array}{l}\text { High } \\
\text { tide }\end{array}$ & $\begin{array}{l}\text { Low } \\
\text { Tide }\end{array}$ & $\begin{array}{l}\text { High } \\
\text { tide }\end{array}$ & $\begin{array}{l}\text { Low } \\
\text { tide }\end{array}$ & Spring & Summer & Spring & Summer \\
\hline $\begin{array}{l}\text { Exposure pathway } \\
\text { Parameter (unit) }\end{array}$ & & & & & & & & & & \\
\hline Shoreline recreation & & & & & & & & & & \\
\hline Distance (metres) & 1000 & 1000 & 1000 & 1000 & 500 & 500 & 1500 & 1500 & 1550 & 1550 \\
\hline Frequency (per year) & 105 & 105 & 105 & 105 & 10 & 10 & 55 & 65 & 25 & 40 \\
\hline $\begin{array}{l}\text { Exposure group } \\
\text { (persons) }\end{array}$ & 100 & 100 & 50 & 50 & 50 & 50 & 50 & 50 & 50 & 50 \\
\hline Ingestion (millilitres) & 22.8 & 22.8 & 22.8 & 22.8 & 22.8 & 22.8 & 22.8 & 22.8 & 22.8 & 22.8 \\
\hline
\end{tabular}




\begin{tabular}{|c|c|c|c|c|c|c|c|c|c|c|}
\hline \multicolumn{11}{|l|}{ Small craft boating } \\
\hline Distance (metres) & 1000 & 3000 & 1000 & 2000 & 250 & 250 & 1500 & 1500 & 1550 & 1550 \\
\hline Frequency (per year) & 105 & 105 & 105 & 105 & 10 & 10 & 40 & 65 & 25 & 50 \\
\hline $\begin{array}{l}\text { Exposure group } \\
\text { (persons) }\end{array}$ & 100 & 100 & 50 & 50 & 50 & 50 & 50 & 50 & 40 & 50 \\
\hline Ingestion (millilitres) & 34.8 & 34.8 & 34.8 & 34.8 & 34.8 & 34.8 & 34.8 & 34.8 & 34.8 & 34.8 \\
\hline \multicolumn{11}{|l|}{ Netfishing } \\
\hline Distance (metres) & 1500 & 3000 & 2000 & 2000 & 1000 & 1000 & 1500 & 1500 & 1550 & 1550 \\
\hline Frequency (per year) & 85 & 85 & 85 & 85 & 10 & 10 & 35 & 50 & 35 & 50 \\
\hline $\begin{array}{l}\text { Exposure group } \\
\text { (persons) }\end{array}$ & 100 & 100 & 50 & 50 & 50 & 50 & 50 & 50 & 50 & 50 \\
\hline Ingestion (millilitres) & 58.0 & 58.0 & 58.0 & 58.0 & 58.0 & 58.0 & 58.0 & 58.0 & 58.0 & 58.0 \\
\hline \multicolumn{11}{|l|}{ Shellfish harvesting } \\
\hline Distance (metres) & - & 2000 & - & 1000 & - & - & - & - & - & - \\
\hline Frequency (per year) & - & 40 & - & 40 & - & - & - & - & - & - \\
\hline $\begin{array}{l}\text { Exposure group } \\
\text { (persons) }\end{array}$ & - & 100 & - & 50 & - & - & - & - & - & - \\
\hline Ingestion (millilitres) & - & 50.0 & - & 50.0 & - & - & - & - & - & - \\
\hline \multicolumn{11}{|l|}{ Shellfish consumption } \\
\hline Distance (metres) & - & 2000 & - & 1000 & - & - & - & - & - & - \\
\hline Frequency (per year) & - & 40 & - & 40 & - & - & - & - & - & - \\
\hline $\begin{array}{l}\text { Exposure group } \\
\text { (persons) }\end{array}$ & - & 400 & - & 200 & - & - & - & - & - & - \\
\hline Ingestion (grams) & - & 75.0 & - & 75.0 & - & - & - & - & - & - \\
\hline \multicolumn{11}{|l|}{ Wetland travel } \\
\hline Distance (metres) & - & - & - & - & - & - & 500 & 500 & 250 & 250 \\
\hline Frequency (per year) & - & - & - & - & - & - & 50 & 50 & 35 & 45 \\
\hline $\begin{array}{l}\text { Exposure group } \\
\text { (persons) }\end{array}$ & - & - & - & - & - & - & 50 & 50 & 50 & 50 \\
\hline Ingestion (millilitres) & - & - & - & - & - & - & 50.0 & 50.0 & 50.0 & 50.0 \\
\hline
\end{tabular}

Table cells denoted with "-" indicate that the exposure pathway is not applicable to that case study location and/or set of receiving environment conditions.

288 The discharge method and timing at each wastewater treatment site are important considerations in 289 defining the human activity parameters of the model as these operational procedures impact the 290 frequency of potential exposure events. The mechanical plants in Iqaluit and Pangnirtung discharge 291 effluent into the receiving environment continuously, year-round. In Sanikluaq and Naujaat, 292 wastewater is contained frozen in stabilization ponds throughout the winter until the spring thaw 
begins. Then, during the 12 to 15 weeks where temperatures remain above freezing, wastewater

294 effluent of varying volume and microbial concentration seeps intermittently into the adjacent wetland 295 and marine waters; this creates a window of time when human exposures may occur. In Pond Inlet, 296 wastewater is also treated using a stabilization pond, which thaws in the spring and freezes in the early 297 fall. It differs from Sanikiluaq and Naujaat, however, in that the pond has been partially engineered to 298 prevent seepage. The wastewater is contained within the cell throughout and summer and then 299 300 manually decanted into the marine receiving environment using a pump over a two to three week period just prior to winter freeze-up. Based on the community data regarding awareness of hazards, it was assumed that there is no human contact with wastewater directly in the stabilization ponds.

Therefore, the only time period that exposures can occur in Pond Inlet is during the short period when 303 this controlled decanting is taking place.

Another important consideration when determining parameters is the extended periods of daylight nearly 24-hour in some locations - in the Arctic during the summer months. This is a lively season in Arctic communities during which people spend a lot of time outdoors engaged in recreational and food harvesting activities. This, in turn, creates potential for high exposure event frequencies and large exposed groups. The total population of each community also invariably factors into the assumed exposed population group.

\subsubsection{Pathogen concentration modelling within receiving environment}

313 An indirect exposure assessment method was used to estimate pathogen concentrations at human 314 exposure points within the effluent receiving environment. A dataset of indicator E. coli concentrations 315 in effluent-impacted wetlands and marine waters that had been collected as part of a previous research program was sourced and repurposed (Greenwood, 2016; Hayward et al., 2018; Huang et al., 2017; 
Neudorf et al., 2017; Ragush et al., 2015). The sampling method involved collecting water samples

from treatment system outfalls and at several points within the receiving environments. In communities discharging directly to marine waters (Iqaluit, Pangnirtung, and Pond Inlet), sampling occurred during both high and low tidal conditions, when safely possible, as water exchange within the receiving environment greatly influences contaminant concentration (Gunnarsdóttir et al., 2013). When possible,

a dye tracer was used to provide a visual indication of wastewater discharge plumes within marine water environments and sampling sites were chosen in locations where the dye concentrations were highest, as well as at the visual boundaries of the plumes. In wetland receiving environments (Sanikiluaq and Naujaat), samples were collected at various points along the predominant stream of discharged effluent. Sampling cycles were conducted during spring freshet and late summer as conditions in wetland receiving environments are highly variable over the treatment season (Hayward et al., 2014; Yates et al., 2012). To analyze for indicator E. coli in the collected wastewater samples from Iqaluit, Pangnirtung, and Pond Inlet, the Colilert-18 method was followed using the QuantiTray/2000 system, in accordance with manufacturer’s instructions (IDEXX Laboratories Inc., 2013). The water samples from Naujaat and Sanikiluaq were analyzed according to standard methods at the commercial laboratory Maxxam Analytics in Montréal, Quebec, Canada (APHA, 2012). Neudorf et al. (2017), Greenwood (2016), and Hayward et al. (2018) provide full descriptions of the wastewater sampling methods and the indicator E. coli analysis. Concentrations were provided as the most probable number of $E$. coli in $100 \mathrm{~mL}(\mathrm{MPN} / 100 \mathrm{~mL})$.

Given that most of the human interactions with the receiving environment occur beyond the distance ranges that were sampled in the original dataset, it was necessary to infer representative concentration values at the theorized exposure points. To do so, a first-order kinetic model was applied to estimate reductions in microorganism concentrations at varying distances from the release point. This type of 
model is widely used to characterize microbial decay or inactivation within environmental systems

342 (Haas et al., 2014; Stetler et al., 1992). In fact, the use of such hydrodynamic modelling of

343 contamination events in combination with QMRA is steadily gaining merit over traditional water

344 quality monitoring of recreational waters in many public health jurisdictions (Ashbolt et al., 2010;

345 Ferguson et al., 2007; McBride et al., 2012; Sokolova et al., 2015; WHO, 2016). First, the natural

346 logarithms of observed E. coli concentrations in the receiving environments at each treatment site were

347 plotted and linearly regressed against distance from the effluent release points. From this, first order

348 concentration reduction constants $\left(\mathrm{m}^{-1}\right)$ were derived from the slope of the line for each of the case

349 study locations under varying conditions.

351 Cut-points were set at distances where it appeared that concentrations detected had reached background 352 levels in the receiving waters and were not directly related to effluent releases. Background levels were 353 set at $<10 \mathrm{MPN} / 100 \mathrm{~mL}$ based on concentration measurements taken at non-effluent impacted 354 reference sites. In instances where multiple samples had been collected at the same distance, the 355 highest concentration was chosen. For censored data (greater or less than method detection limit), we 356 used the detection limit (minimum detection limit was $1 \mathrm{MPN} / 100 \mathrm{~mL}$ ) as the measured value.

357 Graphing and statistical analyses were conducted using SigmaPlot (2014). A summary table of the 358 modelling coefficients used for predicting E. coli concentration in effluent-impacted receiving 359 environments is available in the supplementary material. The calculated reduction constants $(k)$ from 360 the regressions were then used in a first-order model (Equation 1) to predict E. coli concentrations at 361 points of human exposure $\left(C_{d}\right)$ as a function of initial concentrations at effluent release points $\left(C_{0}\right)$ and 362 distance $(d)$, under similar conditions. The model constants represented varying levels of concentration 363 reduction due to dilution, inactivation, and sedimentation associated with the different receiving 364 environments and tidal conditions. 
367 Concentration of $E$. coli within receiving environments was the only available indicator organism 368 dataset. It was assumed that, in the absence of other indicators, the inactivation or dilution of E. coli 369 within these conditions can be used to conservatively predict the reduction of specific pathogens 370 (Nevers and Boehm, 2011; Schoen and Ashbolt, 2010). Published ratios were used to infer levels of 371 other enteric pathogens from the indicator E. coli results (Table 3). When a ratio from wastewater was not available, information sourced from surface water or drinking water was used. An inference ratio of indicator E. coli to pathogenic Salmonella was not available. In lieu, the ratio between non-pathogenic and pathogenic strains of Salmonella was used in the model (Fuhrimann et al., 2016; Hynds et al., 375 2014; Shere et al., 2002; Soller et al., 2010). quantitative microbial risk assessment (QMRA) model estimating acute gastrointestinal illness (AGI) attributable to wastewater treatment systems in Arctic Canada.

\begin{tabular}{lll}
\hline Pathogen & Ratio (E. coli: Path) & References \\
\hline Pathogenic E. coli & $1: 0.08$ & Haas et al. (1999); Howard et al. (2006) \\
Salmonella spp. & $1: 0.01$ & $\begin{array}{l}\text { Fuhrimann et al. (2016); Hynds et al. (2014); Shere et al. } \\
\end{array}$ \\
Campylobacter spp. & $1: 10^{-5}$ & WHO (2006) \\
Rotavirus & $1: 10^{-5}$ & Fuhrimann et al. (2017); Katukiza et al. (2013) \\
Giardia spp. & $1: 10^{-5}$ & Machdar et al. (2013) (general protozoa ratio) \\
Cryptosporidium spp. & $1: 10^{-6}$ & Fuhrimann et al. (2017) \\
\hline
\end{tabular}

381 In the shellfish consumption exposure scenario, it was also necessary to estimate the concentration of 382 contaminants within the bivalve tissue based on the indicator E. coli concentration in the overlying 383 marine water at the harvest locations. There is great variation in accumulation factors presented within 
the literature due to differences in water columns, sewage content, and species between studies. An accumulation factor of 10 was chosen based on a critical review of available data (CEFAS, 2014).

\subsection{Dose-Response Models}

Dose-response models are mathematical functions that are used to predict the relationship between level of microbial exposure and probability of adverse health outcomes. Two dose-response models, the single-parameter exponential function (Equation 2) or the two-parameter beta-Poisson (Equation 3), have proven widely applicable to most microorganisms and exposure routes (Haas et al., 2014).

$P(d)=1-e^{-k d}$

When using the exponential function (Equation 2), $P(d)$ represents the probability of infection and $d$ is a single dose at exposure. The base of the natural logarithm $(e)$ and the probability that one organism survives to initiate the health outcome $(k)$ are pathogen infectivity constants.

$$
P(d)=1-\left[1+\left(\frac{d}{N_{50}}\right) \cdot\left(2^{1 / \alpha}-1\right)\right]^{-\alpha}
$$

With the beta-Poisson function shown in Equation 3, $P(d)$ represents the probability of infection and $d$ a single dose at exposure, with model slope parameter $\alpha$ and median effective dose $N_{50}$. The data analyses used to develop the functions originates primarily from clinical trials (Haas et al., 2014). The dose-response model and parameters recommended for most circumstances were used and are presented in Table 4 (CAMRA, 2015). To determine the proportion of infections that result in applied (Table 5). 
Dose-response models and parameters for use in the quantitative microbial risk assessment (QMRA) estimating acute gastrointestinal illness (AGI) attributable to wastewater treatment systems in Arctic Canada.

\begin{tabular}{|c|c|c|c|}
\hline Pathogen & Model & Parameters & References \\
\hline Pathogenic E. coli & Beta-Poisson & $\alpha=0.16$ & CAMRA (2015); Dupont et al. (1971) \\
\hline (EIEC) & & $\mathrm{N}_{50}=2.11 \times 10^{6}$ & \\
\hline Salmonella spp. & Beta-Poisson & $\begin{array}{l}\alpha=0.389 \\
N_{50}=1.68 \times 10^{4}\end{array}$ & $\begin{array}{l}\text { CAMRA (2015); McCullough and Eisele } \\
\text { (1951) }\end{array}$ \\
\hline Campylobacter spp. & Beta-Poisson & $\begin{array}{l}\alpha=0.14 \\
N_{50}=890.38\end{array}$ & Black et al. (1988); CAMRA (2015) \\
\hline Rotavirus & Beta-Poisson & $\begin{array}{l}\alpha=0.253 \\
N_{50}=6.17\end{array}$ & CAMRA (2015); Ward (1986) \\
\hline Giardia spp. & Exponential & $k=0.020$ & CAMRA (2015); Rendtorff (1954) \\
\hline Cryptosporidium spp. & Exponential & $k=0.057$ & CAMRA (2015); Messner et al. (2001) \\
\hline
\end{tabular}

412
Morbidity ratios estimating probability of illness condition upon infection for selected pathogens $\left(\mathrm{P}_{\mathrm{ill}}\right.$ | inf $)$ for use in the quantitative microbial risk assessment (QMRA) of acute gastrointestinal illness (AGI) attributable to wastewater treatment systems in Arctic Canada.

\begin{tabular}{|c|c|c|}
\hline Pathogen & Probability ( $\left.P_{\text {ill } \mid \text { inf }}\right)$ & References \\
\hline Pathogenic E. coli & 0.35 & $\begin{array}{l}\text { Fuhrimann et al. (2017); Machdar et al. (2013); Westrell } \\
\text { (2004) }\end{array}$ \\
\hline Salmonella spp. & 0.80 & Westrell (2004); WHO (2006) \\
\hline Campylobacter spp. & 0.30 & $\begin{array}{l}\text { Fuhrimann et al. (2017); Machdar et al. (2013); Westrell } \\
\text { (2004) }\end{array}$ \\
\hline Rotavirus & 0.50 & Barker et al. 2014; Westrell (2004); WHO (2006) \\
\hline Giardia spp. & 0.90 & Schoen and Ashbolt (2010) \\
\hline Cryptosporidium spp. & 0.79 & Fuhrimann et al. (2017) \\
\hline
\end{tabular}

\subsection{Risk characterization}

The health outcome measures included in the model are expected annual cases of AGI, expected annual incidence of AGI per total population and 1000 persons, and estimated probability of AGI per person per year for a single exposure event. Although some of these endpoints may not be as common across global literature as disability-adjusted life years, they were chosen for their direct comparability to the limited epidemiological studies of AGI in Arctic Canada (Harper et al., 2015), while still being 
423 relatable to disease burden measures used in some QMRA studies of wastewater exposures in other 424 regions (Fuhrimann et al., 2017, 2016).

425

426 The risk characterization equations used to estimate these outcomes are based on adapted versions from 427 Haas et al. (2014), Howard et al. (2006), WHO (2016), Sales-Ortells and Medema (2014), and

428 Fuhrimann et al. (2017, 2016). The model was developed using Microsoft Excel (2010) and is available 429 in the supplementary material.

430

431 Using the data described in the methods section, individual probabilities of infection and illness were 432 calculated with equations 4 thru 6:

433

$434 \quad D_{E . \text { coli }}=C * V$

435

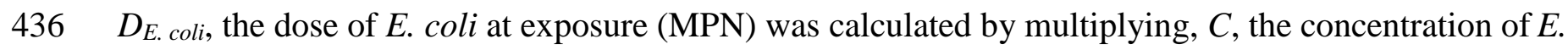
437 coli at the exposure distance $(\mathrm{MPN} / \mathrm{mL})$ by $V$, the volume of water or tissue (mL or g) ingested per 438 exposure event.

439

440

$D_{\text {path }}=D_{\text {E. coli }} *($ E. coli: Path $)$

441

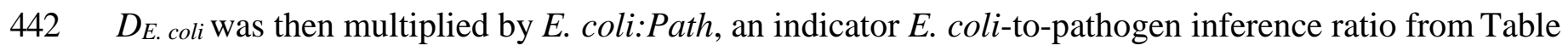
443 3, to produce the corresponding pathogen-specific dose at exposure, $D_{\text {path }}(\mathrm{MPN})$. The obtained doses 444 of each pathogen, $D_{\text {path }}$, were then entered into corresponding dose-response models (Equations 3 and 445 4), described in section 2.5, with parameters from Table 4 to obtain individual probability of infection 


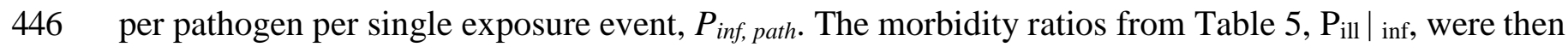
447 applied to determine the probability of illness per pathogen, per exposure pathway, $\mathrm{P}_{\text {ill,path }}$ (Equation6).

448

449

$$
P_{i l l, p a t h}=P_{\text {inf,path }} * P_{\text {ill } \mid \text { inf }}
$$

450

451 Within the model, it was assumed that each exposure event was independent, that people can become 452 ill from more than one hazard at the same time, and there was no acquired immunity after a previous 453 infection (Haas et al., 2014). It was also assumed that a person could belong to any, or all, of the 454 exposed groups within the community that they reside (e.g. a resident of Iqaluit could be a shellfish 455 harvester as well as participate in netfishing). These assumptions allowed for summations to be 456 performed (Equations 7, 8, 9, and 10), based on the probability of illness, $\left(P_{\text {ill,path }}\right)$. 457

$P_{\text {ill,path,total }}=\sum P_{i l l, p a t h}$

458 The total probability of illness caused by any pathogen per person per single exposure event 459 ( $\left.P_{\text {ill,path,total }}\right)$ was obtained by summing the probabilities of illness $\left(P_{\text {ill,path }}\right)$ of every pathogen for a given 460 exposure pathway.

461

$$
\text { Cases }_{\text {path }}=\sum_{i=1}^{(\text {Freq)(ExpGroup) }} P_{\text {ill,path }}
$$

463 Cases $_{\text {path }}$ represents the annual number of expected AGI cases per pathogen per exposurescenario, 464 incorporating frequency of exposure events per year, Freq, and exposure group per single event, 465 ExpGroup, from the human activity data (Table 2). 


$$
\text { Cases }_{\text {all path }}=\sum \text { Cases }_{\text {pathi } \ldots . . j}
$$

467

468 Summing all of the individual pathogen-specific cases, Casespath, provided the annual number of 469 expected AGI cases per exposure scenario, Cases all path

470

Cases $_{\text {all path,location }}=\sum$ Cases $_{\text {allpath }}$

471 Finally, summing all of the cases attributable to each exposure scenario, Casesall path, provided the total 472 expected annual AGI cases attributable to wastewater exposure, per case study location, Casesall 473 path,location.

474 475 476 477

Inc $_{\text {location }}=\frac{\text { Cases }_{\text {all path,location }}}{\text { Pop }_{\text {location }}}$

479 Annual individual incidence rate of AGI per location is denoted by Inclocation. Location population sizes, 480 Poplocation, were presented in Table 1.

481

Inc $_{\text {location }, 1000}=$ Inc $_{\text {location }} * 1000$

482 
In turn, Inclocation, was multiplied by 1000 to provide comparable annual rates of individualincidence

484

485

486

487 488

489

490

491

492

493

494

495

496

497

498

499

500

501

502

503

504 rates per 1000 persons, per location (Inclocation, 1000). Secondary transmissions and sensitives

subpopulations were not included in the model.

\section{Results and discussion}

Model results should be evaluated in the context of a screening-level point estimate assessment based on worst case conditions aiming to provide the first assessments of AGI attributable specifically to wastewater exposures in Arctic Canada. Given the uncertainty and variability inherent in the data, the relative risk between scenarios is of greater importance than absolute risk values. In exploring relative risk, elements of the system that warrant further assessment are discussed and risk management ideas are presented.

\subsection{Expected total annual cases of AGI}

The expected annual AGI cases attributable to wastewater exposures, by case study location, are presented in Table 6. The highest estimate of AGI cases per location occurs in Pangnirtung at 7416.16 episodes of AGI per year. Naujaat and Iqaluit follow with 1251.44 and 994.45 respective annual estimated cases. Considerably fewer cases are estimated in Pond Inlet and Sanikiluaq (36.73 and 3.65 episodes per year, respectively).

\section{Table 6}

Expected annual cases of acute gastrointestinal illness (AGI) attributable to wastewater treatment systems in five arctic case study locations, per receiving environment conditions and exposure pathway, as estimated using a quantitative microbial risk assessment (QMRA).

\begin{tabular}{lcccccccccc}
\hline $\begin{array}{l}\text { Case study } \\
\text { location }\end{array}$ & \multicolumn{2}{c}{ Iqaluit } & \multicolumn{2}{c}{ Pangnirtung } & Pond Inlet & Sanikiluaq & Naujaat \\
\hline $\begin{array}{l}\text { Receiving } \\
\text { environment }\end{array}$ & High & Low & High & Low & High & Low & Spring & Summer & Spring & Summer \\
\hline
\end{tabular}


conditions

\section{Exposure pathway}

Shore

recreation

$2.45 \times \quad 796.4 \leq 1.00 \quad 507.81$

$10^{-11} \quad 8 \times 10^{-16}$

$3.03 \leq 1.00 \times 0.0003$

$2.63 \times$

6.42

$8.01 \times$

Smallcraft

$3.85 \times$

$0.10 \leq 1.00 \quad 711.09$

$33.59 \leq 1.00 \times 0.0003$

$10^{-9}$

$10^{-6}$

Small craft

$10^{-11}$

$\times 10^{-16}$

$4.01 \times$

9.73

$1.22 \times$

boating

Netfishing

$$
\begin{array}{r}
\leq 1.00 \times \\
10^{-16}
\end{array}
$$

$0.13 \leq 1.00$

841.09

$\times 10^{-16}$
$10^{-16}$
$0.11 \leq 1.00 \times 0.0005$
$10^{-16}$

$10^{-9}$

$10^{-5}$

$5.14 \times$

22.43

$2.55 \times$

$10^{-9}$

$10^{-5}$
Shellfish
\begin{tabular}{l}
$-\quad 6.54$ \\
\hline
\end{tabular}
- 355.62
harvesting
Shellfish
- 191.2
- 5000.5
consumption

0
5

Wetland

$-$

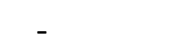

travel

Total

994.45

7416.16

$-$

$-\quad 3.6$

$0.0063 \quad 1050.4$

162.44

Table cells denoted with "-" indicate that the exposure pathway is not applicable to that case study location.

506

In both of the locations operating mechanical wastewater treatment plants, Iqaluit and Pangnirtung, all

of the estimated cases occur during low tide conditions. This finding suggests that the continuous

discharge of effluent during this period, when the sea bed is exposed and only minimal dilution can

occur, creates a period of potentially elevated human health risk. Studies of the marine environmental

514 scheduled window during which effluent is discharged from the WSP (two to three weeks in later

515 summer) and because there are fewer exposure pathways in Pond Inlet. The explanation for the cases

516 occurring at high tide - contrary to low tide as seen in Iqaluit and Pangnirtung - may be due to

517 differences in system siting and receiving environments. At the Pond Inlet site, the treatment system is

518 located approximately two kilometres away from the central area of the community, where most human 
activity occurs. Also effluent is discharged into open marine waters, where the sea bed is not exposed,

520 and effluent quickly mixes with seawater (Greenwood, 2016; Ragush et al., 2015). In Iqaluit and

521 Pangnirtung, the treatment plants are directly within the main settlements and effluent is discharged

522 into more shallow, enclosed waters between tapering shores (Greenwood, 2016; Neudorf et al., 2017).

523 At the Pond Inlet site it was observed, however, that high winds combined with a strong ambient

524 current cause the discharged effluent plume to attach to the shoreline and drift toward the central area

525 of the community (Greenwood, 2016; Krumhansl et al., 2015). This phenomenon is reflected in the

526 model output with the resulting 36.73 estimated cases of AGI.

527

528 Of the two locations relying on WSP treatment systems with an adjoining wetland, only the estimated 5291251.44 annual cases of AGI in Naujaat suggest potential cause for immediate concern. The majority 530 of the cases (87\%) in Naujaat are estimated to occur during spring. At this time, the WSP is melting 531 quickly and a high volume of minimally-treated effluent is flowing rapidly through the wetland and 532 into the ocean (Hayward et al., 2018). Key informants from the community also noted that this period 533 coincides with a time of increased human activity near the treatment wetland. People travelling by all534 terrain vehicles or snowmobile reroute inland as travel over the melting sea ice near shore is no longer 535 safe. In combination, these results and factors suggest that low frequency, short term events may dictate 536 conditions of higher risk in pond and wetland systems. These events include foreseeable occurrences such as scheduled decants or annual spring freshets as well as less predictable episodes such as highprecipitation levels or failed treatment due to unmaintained or undersized WSPs. Even if risks appear 539 low the majority of the time, understanding these drivers may help effectively control exposures 540 through public health advisories or changes to operational procedures, for instance - when those conditions periodically occur. 
543 Among the suite of pathogens modelled, rotavirus (46\%) and Salmonella spp. (32\%) contribute the

544 highest percentages of cases to the combined total AGI burden for all five locations. The remaining 545 percent allocations are Giardia spp. at 10\%, pathogenic E. coli at 6\%, and Campylobacter spp. and 546 Cryptosporidium spp. at 3\% each (full results of AGI cases by pathogen, per exposure pathway not 547 shown, but available with the risk model in supplementary material). Attributing AGI cases to specific 548 pathogens based on these QMRA results, however, must be done with caution. The model used to 549 predict pathogen concentrations within the receiving environment is based solely on E. coli as an 550 indicator organism and then uses inference ratios. Minimal account was given to the difference in 551 environmental persistence between pathogens. Salmonella spp. along with Campylobacter spp. and 552 Giardia spp. are believed to die-off in seawater exposed to sunlight in less than 24 hours, which may 553 reduce the number of infections; however, microbial inactivation is highly variable (Bitton, 2005;

554 Johnson et al., 1997; Schoen and Ashbolt, 2010). Viruses and Cryptosporidium spp. do have potential 555 to persist in seawater for several days (Johnson et al., 1997; Noble et al., 2004; Schoen and Ashbolt, 556 2010), which may prove of importance as high rates of rotavirus infection in the Arctic have been 557 documented (Desai et al., 2017; Goldfarb et al., 2013; Gurwith et al., 1983).

\subsection{Expected annual incidence rates of AGI}

560 The expected annual incidence rates per person, corresponding to the total population, and per 1000 561 persons in each case study location are shown in Table 7. For comparison, the incidence rate results 562 table also includes an estimate of all food- and waterborne AGI in Arctic communities that is based 563 upon a cross-sectional retrospective epidemiological survey (Harper et al., 2015). 
persons as estimated using a quantitative microbial risk assessment (QMRA) in five arctic case study locations, with comparison to all food- and waterborne AGI arctic estimate (Harper et al., 2015).

\begin{tabular}{lllllll}
\hline $\begin{array}{l}\text { Case study } \\
\text { location }\end{array}$ & Iqaluit & Pangnirtung & Pond Inlet & Sanikiluaq & Naujaat & $\begin{array}{l}\text { All food- and waterborne } \\
\text { AGI Arctic estimate } \\
\text { (Harper et al., 2015) }\end{array}$ \\
\hline Population & 7740 & 1481 & 1671 & 882 & 1082 & Not applicable \\
$\begin{array}{l}\text { Incidence } \\
\text { rate per } \\
\text { person }\end{array}$ & 0.13 & 5.01 & 0.02 & 0.004 & 1.16 & $2.9-3.9$ \\
$\begin{array}{l}\text { Incidence } \\
\text { rate per } \\
\begin{array}{l}1000 \\
\text { persons }\end{array}\end{array}$ & 128.48 & 5007.53 & 21.98 & 4.13 & 1156.59 & $2900-3900$ \\
\hline
\end{tabular}

In four of the five case study locations, estimates of AGI incidence attributed to wastewater exposure are below the minimum range of Harper et al.’s (2015) estimate of 2.9-3.9 cases per person per year for all food- and waterborne exposures. The study by Harper et al. (2015) included an assortment of potential risk factors in Arctic communities such as diet, drinking water source, exposure to pets, and in-home conditions. It follows then that the annual incidence rates per person from Iqaluit (0.13), Pond Inlet (0.02), and Sanikiluaq (0.004) seem reasonable estimates of the proportion of AGI attributable to wastewater exposure, with Naujaat (1.16) being moderately high but plausible. The per person incidence rate estimate for Pangnirtung (5.01) is very high. In comparison to some other environments where populations may be indirectly exposed to wastewater pathogens, the Pangnirtung AGI incidence rate per person is in between that of urban farmers in Hanoi, Vietnam (1.98) and Kampala, Uganda (10.92); both locations where agricultural fields are flooded with partially treated effluent (Fuhrimann et al., 2017, 2016). On one hand, it is prudent to recall that the result is a modelled projection of maximum exposure in an arctic community, including a period of low tide conditions, with effluent 
the other hand, the model is demonstrating that, in the worst case scenario, potential does exist for an outbreak of waterborne disease.

Comparison of the two pond-and-wetland sites, Naujaat and Sanikiluaq, highlights the variation of potential human health risks even amongst seemingly alike passive systems. Both communities are similar in terms of total population, discharge method, annual volume of wastewater, and the types of exposure pathways, as presented in Tables 1 and 2. However, the annual incidence per person rate in Naujaat (1.16) is more than two orders of magnitude greater than that in Sanikiluaq (0.004). One reason for this difference is the design and condition of the WSPs and their effectiveness in reducing pathogen loads within effluent prior to seepage into the wetland (Hayward et al., 2018). In Naujaat, for instance, the initial indicator E. coli concentration (MPN/100 mL) observed at the pond outlet during spring freshet is $1.73 \times 10^{6}$, compared to only $6.04 \times 10^{4}$ in Sanikiluaq.

\subsection{Estimated probability of AGI per single exposure event}

This study placed emphasis on soliciting community input and feedback during the development and parameterization of the exposure scenarios. The estimated probabilities of AGI per person per a single exposure event for each scenario are presented in Table 8. The probabilities correspond to AGI attributable to any of the modelled pathogens. Many of the risk probabilities are very low $\left(\leq 2.50 \times 10^{-}\right.$

${ }^{6}$ ) including all exposures occurring during high tide conditions in Iqaluit and Pangirtung, all exposures occurring during low tide conditions in Pond Inlet, all exposures occurring during late summer conditions in Naujaat with the exception of wetland travel (0.0722), and all exposures entirely in Sanikiluaq with the exception of wetland travel during spring (0.002). 

calculated using a quantitative microbial risk assessment (QMRA) model.

\begin{tabular}{|c|c|c|c|c|c|c|c|c|c|c|}
\hline \multirow{2}{*}{$\begin{array}{l}\begin{array}{l}\text { Case study } \\
\text { location }\end{array} \\
\text { Receiving } \\
\text { environment } \\
\text { conditions }\end{array}$} & \multicolumn{2}{|c|}{ Iqaluit } & \multicolumn{2}{|c|}{ Pangnirtung } & \multicolumn{2}{|c|}{ Pond Inlet } & \multicolumn{2}{|c|}{ Sanikiluaq } & \multicolumn{2}{|c|}{ Naujaat } \\
\hline & $\begin{array}{l}\text { High } \\
\text { tide }\end{array}$ & $\begin{array}{l}\text { Low } \\
\text { tide }\end{array}$ & $\begin{array}{l}\text { High } \\
\text { tide }\end{array}$ & $\begin{array}{l}\text { Low } \\
\text { tide }\end{array}$ & $\begin{array}{l}\text { High } \\
\text { tide }\end{array}$ & Low tide & Spring & Summer & Spring & Summer \\
\hline $\begin{array}{l}\text { Exposure } \\
\text { pathway }\end{array}$ & & & & & & & & & & \\
\hline $\begin{array}{l}\text { Shore } \\
\text { recreation }\end{array}$ & $\begin{array}{c}2.33 \times \\
10^{-13}\end{array}$ & 0.076 & $\begin{array}{r}\leq 1.00 \times \\
10^{-16}\end{array}$ & 0.097 & 0.006 & $\begin{array}{r}\leq 1.00 \times \\
10^{-16}\end{array}$ & $\begin{array}{r}1.05 \times \\
10^{-7}\end{array}$ & $\begin{array}{r}8.08 \times \\
10^{-13}\end{array}$ & 0.005 & $\begin{array}{r}4.0 \times \\
10^{-9}\end{array}$ \\
\hline $\begin{array}{l}\text { Small craft } \\
\text { boating }\end{array}$ & $\begin{array}{c}3.66 \times \\
10^{-15}\end{array}$ & $\begin{array}{r}9.40 \times \\
10^{-6}\end{array}$ & $\begin{array}{r}\leq 1.00 \times \\
10^{-16}\end{array}$ & 0.135 & 0.067 & $\begin{array}{r}\leq 1.00 \times \\
10^{-16}\end{array}$ & $\begin{array}{r}1.61 \times \\
10^{-7}\end{array}$ & $\begin{array}{r}1.23 \times \\
10^{-12}\end{array}$ & 0.008 & $\begin{array}{r}6.11 \times \\
10^{-9}\end{array}$ \\
\hline Netfishing & $\begin{array}{r}\leq 1.00 \times \\
10^{-16}\end{array}$ & $\begin{array}{r}1.57 \times \\
10^{-5}\end{array}$ & $\begin{array}{r}\leq 1.00 \times \\
10^{-16}\end{array}$ & 0.198 & 0.0002 & $\begin{array}{r}\leq 1.00 \times \\
10^{-16}\end{array}$ & $\begin{array}{r}2.68 \times \\
10^{-7}\end{array}$ & $\begin{array}{r}2.06 \times \\
10^{-12}\end{array}$ & 0.013 & $\begin{array}{r}1.02 \times \\
10^{-8}\end{array}$ \\
\hline $\begin{array}{l}\text { Shellfish } \\
\text { harvesting }\end{array}$ & $\begin{array}{r}\leq 1.00 \times \\
10^{-16}\end{array}$ & 0.002 & $\begin{array}{r}\leq 1.00 \times \\
10^{-16}\end{array}$ & 0.178 & - & - & - & - & - & - \\
\hline $\begin{array}{l}\text { Shellfish } \\
\text { consumption }\end{array}$ & $\begin{array}{c}\leq 1.00 \times \\
10^{-16}\end{array}$ & 0.012 & $\begin{array}{r}\leq 1.00 \times \\
10^{-16}\end{array}$ & 0.625 & - & - & - & - & - & - \\
\hline $\begin{array}{l}\text { Wetland } \\
\text { travel }\end{array}$ & - & - & - & - & - & - & 0.002 & $\begin{array}{r}2.50 \times \\
10^{-6}\end{array}$ & 0.600 & 0.072 \\
\hline
\end{tabular}

611 Table cells denoted with "-" indicate that the exposure pathway is not applicable to that case study location

612 and/or set of receiving environment conditions.

613

614 High risk probabilities per single exposure are estimated for shellfishing harvesting (0.178) and

615 consumption (0.625) in Pangnirtung. Lower estimates are seen for these pathways in Iqaluit (harvesting

616 at 0.002 and consumption at 0.012 ) where pathogen concentrations in shellfish harvesting waters were

617 greatly reduced in comparison to Pangnirtung. Studies of microbial contamination within shellfish

618 tissue in the Arctic, for comparative purposes, are limited. Those that have been undertaken found

619 shellfish to be of generally good microbiological quality; however Giardia spp. and Cryptosporidium

620 spp. were present in some samples (Lévesque et al., 2010; Manore et al., 2017). In agreeance with 
621 recommendations from these studies, the range of estimates from this QMRA model suggests a need

622 for continued research on shellfish in Arctic communities. As a more immediate application, these

623 results may be useful in informing economical risk management strategies in Nunavut. In the remote,

624 resource-limited region, risk alleviation via infrastructure upgrades is extremely costly and difficult

625 (Suk et al., 2004). In Pond Inlet for example, wastewater operations staff had previously established a

626 precautionary risk mitigation practice of delaying the annual decant of the WSP into the marine

627 receiving environment until after the migratory passage of Arctic char (Salvelinus alpinus), a fish of

628 great local importance. Given the estimated reduction in risk between low and high tide cycles in

629 Iqaluit and Pangnirtung, a similar control measure could be employed. Adjusting the effluent release

630 schedules at the mechanical treatment plants to discharge primarily during high and outgoing tide

631 cycles, when the greatest water exchange is ensuing (Nevers and Boehm, 2011), may be an effective

632 mitigation effort; particularly during periods of maximum tidal range when most shellfish harvesting

633 takes place.

634

635 Broad community involvement during model development allowed for differing perspectives to be

636 incorporated into the research and exhibits how primary environmental risk factors are influenced by

637 social, cultural, and behavioural determinants in Indigenous communities (Barber and Jackson, 2015;

638 Knibbs and Sly, 2014). For example, in some case study locations the more established food harvesters

639 stated that they never travel nor hunt near wastewater treatment areas; implying that these exposure

640 pathways could be dismissed. Younger residents or those with fewer of the resources necessary to

641 reach prime locations beyond the community boundaries (e.g. all-terrain vehicle, money for fuel and

642 supplies), however, mentioned that they had harvested food in close proximity to the wastewater

643 treatment site. In terms of risk management and communication, this type of community-based

644 information is very important to accurately capture within the QMRA model. For example, in Naujaat, 


\section{$648 \quad 3.4$ Limitations}

649 This initial assessment of a complex socioecological system was conducted using a point estimate, 650 651 652 653 654 655 656 657 658 659 660 661 662 663 664

where an unmarked and unfenced wetland that is used as a travel route is also part of the treatment train, the estimated probability of risk per single wetland travel exposure during spring is 0.60 . “worst-case” scenario model. A point estimate QMRA follows a transparent process making it an effective tool for communicating with multiple stakeholder groups, whom may be unfamiliar with risk assessment concepts (Howard et al., 2006). However, a single number describing risk can lead to a false sense of safety or unnecessary alarm. This QMRA should be considered a first tier, useful for identifying scenarios where a stochastic assessment, including sensitivity analysis of the uncertainty associated with each input, should be conducted.

The specific exposure pathways modelled and parameter values used may or may not be directly transferable to sites outside of the five case study locations as food harvesting practices and recreational activities vary by community. Notwithstanding, this information will serve as a starting point for applying the model in other arctic and northern regions. The treatment type and receiving environment characterizations do broadly categorize most wastewater sites in Arctic Canada. Furthermore, as treatment systems are revamped or operational procedures are adjusted, the model can be used to estimate the change in risk attributable to the improvements.

Indicator E. coli concentrations were the only available indexer of pathogen occurrence within the effluent receiving environments. Reliance on one type of indicator organism inevitably requires many assumptions and introduces additional uncertainty, but many initial QMRAs must be conducted using fecal indicator bacteria due to lack of data (Haas et al., 2014). Fecal coliform analysis, or as was done 
in this study, indicator E. coli analysis may arguably be the best practical indicator of pathogenic

670 organisms in Arctic communities, given the relative ease and low-cost of analysis. The suite of

671 pathogens included in the model were chosen as a representative group of the major microbial hazards

672 present in wastewater effluent, with consideration given to infections in arctic populations. AGI is also 673 attributable to several other waterborne pathogens not included in the suite of six microbial infectious 674 agents. Additional types of waterborne infections, such as eye and skin infections, were not included. 675 Similarly, the occupational risk to wastewater operators was not targeted, as the aim was to assess 676 community risk in the effluent receiving environment.

677

\section{4. Conclusion}

679 A point estimate QMRA was used to provide the first estimates of AGI attributable to wastewater 680 treatment systems in the arctic territory of Nunavut, Canada. A number of exposure pathways and 681 682 683 684 685 686 microbial pathogens were assessed using worst case scenario models based on the types of human activity occurring near effluent receiving environments. High incidence rates are estimated in scenarios where mechanical treatment systems are releasing effluent directly into marine waters at low tide conditions. Moderate risks are also seen in some stabilization pond and treatment wetland sites during seasonal events such as spring freshet. Based on these findings, human exposure to partially treated wastewater effluent may be contributing to high AGI rates in some communities. These results can be used to provide evidence to support public health initiatives as well as decisions regarding water and sanitation infrastructure investment in the region. Follow-up research will involve more complex modelling of the higher risk pathways that have been identified as well as risk mitigation options. 
692 The authors would like to extend gratitude to the community members and key informants in Iqaluit,

693 Pangnirtung, Pond Inlet, Sanikiluaq, and Naujaat who participated in this research. The authors also

694 thank the Hamlet administrations of these communities and the Nunavut Research Institute for their 695 cooperation and support.

696

697 The authors would also like to thank the many Centre for Water Resources Studies team members

698 whose efforts led to the indicator E. coli dataset that was used in the QMRA model: Jennifer Hayward,

699 Mark Greenwood, Colin Ragush, Yannan Huang, Jordan Schmidt, Kara Neudorf, Joanna Poltarowicz,

700 Amy Jackson, Rob Johnson, Aubrey Hiscock, and Meggie Letman. Additionally, the authors are

701 grateful to Tim Anaviapik Soucie and Andrew Arreak for their assistance in Pond Inlet, as well as

702 Anna Manore of the University of Guelph for providing research insight on shellfish harvesting in

703 Iqaluit.

704

705 Funding for this study was provided by the Community and Government Services department of the 706 Government of Nunavut, Aboriginal Affairs and Northern Development Canada, the Nasivvik Centre 707 for Inuit Health and Changing Environments, and the Population Intervention for Chronic Disease 708 Prevention Program. The funding agencies were not involved in conducting the research or preparing 709 this article. The authors have no competing interests to declare.

710

711 Supplementary Material

712 Appendix A. Summary table of Modelling Coefficients for Predicting Indicator E. coli Concentrations 713 in Effluent-Impacted Receiving Environments (Microsoft Word) 714

715 Appendix B. Full QMRA Model (Microsoft Excel) 


\section{References}

718 Ashbolt, N.J., Schoen, M.E., Soller, J.A., Roser, D.J., 2010. Predicting pathogen risks to aid beach

719 management: the real value of quantitative microbial risk assessment (QMRA). Water Res. 44 (16), $720 \quad 4692-4703$.

721

722

APHA (American Public Health Association), 2012. Standard Methods for the Examination of Water 723 and Wastewater. 22nd ed. Water Environment Federation, Washington District of Columbia, United 724 States, p. 1496.

725

726

Barber, M., Jackson, S., 2015. ‘Knowledge making’: issues in modelling local and indigenous 727 ecological knowledge. Hum. Ecol. 43, 119-130.

728

729

730

Barker, S.F., Amoah, P., Dreschsel, P., 2014. A probabilistic model of gastroenteritis risk associated with consumption of street food salads in Kumasi, Ghana: evaluation of methods to estimate pathogen dose from water, produce or food quality. Sci. Total Environ. 487, 130-1142.

732

733

Black, R.E., Levine, M.M., Clements, M.L., Hughes, T.P., Blaser, M.J., 1988. Experimental

Campylobacter jejuni infection in humans. J. Infect. Dis. 157(3), 472-479.

735

Boehm, A.B., Ashbolt, N.J., Colford, J.M., Dunbar, L.E., Fleming, L.E., Gold, M.A., Hansel, J.A., 737 Hunter, P.R., Ichida, A.M., McGee, C.D., Soller, J.A., Weisberg, S.B., 2009. A sea of change ahead for recreational water quality criteria. J. Water Health 7(1), 9-20. 
740 Bitton, G., 2005. Wastewater Microbiology, third ed. Wiley, Hoboken, New Jersey.

741

742 Butt, A.A., Aldridge, K.E., Sanders, C.V., 2004. Infections related to ingestion of seafood. Part I: viral 743 and bacterial infections. Lancet Infect. Dis. 4, 201-212.

744

745 CAMRA (Center for Advancing Microbial Risk Assessment), 2015. Table of recommended best-fit 746 parameters. http://qmrawiki.canr.msu.edu/index.php/Quantitative_Microbial_Risk_Assessment_(QMR 747 A)_Wiki (accessed 4 September 2018).

748

749 CEFAS (Centre for Environment Fisheries \& Aquaculture Science), 2014. A Critical Review of the 750 Current Evidence for the Potential Use of Indicator Species to Classify UK Shellfish Production Areas 751 FS512006. Food Standards Agency, London:p. 83 Retrieved from. https://www.food.gov.uk/science/re 752 search/foodborneillness/b16programme/B16projlist/fs512006, Accessed date: 4 September 2018.

753

754 Collings, P., Wenzel, G., Condon, R., 1998. Modern food sharing networks and community integration 755 in the Central Canadian Arctic. Arctic 51(4), 301-314.

756

757 Daley, K., Castleden, H., Jamieson, R., Furgal, C., Ell, L., 2015. Water systems, sanitation and public 758 health risks in remote communities: Inuit resident perspectives from the Canadian Arctic. Soc Sci Med. 759 135, 124-132.

760

761 Daley, K., Jamieson, R., Rainham, D., Truelstrup Hansen, L., 2017. Wastewater treatment and public 762 health in Nunavut: a microbial risk assessment framework for the Canadian Arctic. Environ. Sci.

763 Pollut. R. https://doi.org/10.1007/s11356-017-8566-8. 
765 Desai, S., Miners, A., Smieja, M., Serra, E., Amagoalik, L., Barker, B., Nishi, W., Yansouni, C.P., 766 Pernica, J.M., Barker, K., Goldfarb, D.M., 2017, December. Results of the multisite Nunavut acute 767 childhood gastrointestinal surveillance project. Paper presented at the ArcticNet International Arctic 768 Change Conference. Quebec City, Canada.

769

770

Dorevitch, S., Panthi, S., Huang, Y., Li, H., Michalek, A.M., Pratap, P., Wroblewski, M., Liu, L., 771 Scheff, P.A., Li, A., 2011. Water ingestion during water recreation. Water Res. 45(5), 2020-2028. 772

Dorevitch, S., Pratap, P., Wroblewski, M., Hryhorczuk, D., Li, H., Liu, L.C., Scheff, P., 2012. Health 774 risks of limited-contact water recreation. Environ. Health Persp. 120(2), 192-197.

775

776

777

Dunn, G., Harris, L., Cook, C., Prystajecky, N., 2014. A comparative analysis of current microbial water quality risk assessment and management practices in British Columbia and Ontario, Canada. Sci. 778 Total Environ. 468-469, 544-552.

779

Dupont, H.L., Formal, S.B., Hornick, R.B., Snyder, M.J., Libonati, J.P., Gheahan, D.G., Labrec, E.H., 781 Kalas, J.P., 1971. Pathogenesis of Escherichia coli diarrhea. New Engl J Med. 285, 1-9. https://doi.org/ 782 10.1056/nejm197107012850101.

783

784 Ferguson, C.M., Croke, B.F., Beatson, P.J., Ashbolt, N.J., Deere, D.A., 2007. Development of a 785 process-based model to predict pathogen budgets for the Sydney drinking water catchment. J. Water 786 Health 5(2),187-208. 
788 Ferrer, A., Nguyen-Viet, H., Zinsstag, J., 2012. Quantification of diarrhea risk related to wastewater

789 contact in Thailand. Ecohealth 9, 49-59.

790

791 Fisheries and Oceans Canada, 2016. Tides, currents, and water levels. http://www.tides.gc.ca/eng/data 792 (accessed 15 February 2018).

793

794 Ford, T., 2005. Water and health, in: Frumkin, H. (Eds.), Environmental health: From global to local. 795 Jossey-Bass, San Francisco, pp. 454-518.

796

797 Fuhrimann, S.,Winkler, M.S., Stalder, M., Niwagaba, C.B., Babu, M., Kabatereine, N., Halage, A.A., 798 Utzinger, J., Cissé, G., Nauta, M., 2016. Disease burden due to gastrointestinal pathogens in a 799 wastewater system in Kampala, Uganda. Microb. Risk Anal. 4, 16-28.

800

801 Fuhrimann, S., Nauta, M., Pham-Duc, P., Thuy Tram, N., Nguyen-Viet, H., Utziner, J., Cissé, G., 802 Winkler, M.S., 2017. Disease burden due to gastrointestinal infections among people living along the 803 major wastewater system in Hanoi, Vietnam. Adv. Water Resour. 108, 439-449.

804 http://dx.doi.org/10.1016/j.advwatres.2016.12.010. 805

806 Goldfarb, D.M., Dixon, B., Moldovan, I., Barrowman, N., Mattison, K., Zentner, C., Baikie, M., 807 Bidawid, S., Chan, F., Slinger, R., 2013. Nanolitre real-time PCR detection of bacterial, parasitic, and 808 viral agents from patients with diarrhoea in Nunavut, Canada. Int. J. Circumpol. Heal. 72, 19903. 809 
810 Greenwood, M., 2016. Assessment of Water Quality Impacts in Marine Environments Receiving

811 Municipal Wastewater Effluent Discharges in Nunavut, M.ASc. thesis, Dalhousie University, Halifax, 812 Canada. Retrieved from. https://dalspace.library.dal.ca/xmlui/handle/10222/11163/browse?type=autho 813 r\&value=Greenwood\%2C+Mark, Accessed date: 5 September 2018.

814

815 Gunnarsdóttir, R., Jenssen, P., Jensen, P.E., Villumsen, A., Kallenborn, R., 2013. A review of 816 wastewater handling in the Arctic with special reference to pharmaceuticals and personal care products 817 and microbial pollution. Ecol. Eng. 50, 76-85.

818

819 Gurwith, M., Wenman, W., Gurwith, D., Brunton, J., Feltham, S., Greenberg, H., 1983. Diarrhea 820 among infants and young children in Canada: a longitudinal study in three northern communities. J. 821 Infect. Dis. 147, 685-692.

822

823 Haas, C.N., Rose, J.B., Gerba, C.P., 2014. Quantitative Microbial Risk Assessment second ed. Wiley 824 Publishing, Hoboken, New Jersey.

825

826 Haas, C.N., Rose, J.B., Gerba, C.P., 1999. Quantitative Microbial Risk Assessment, first ed. John 827 Wiley and Sons, Hoboken, New Jersey.

828

829 Harper, S.L., Edge, V.L., Ford, J., Thomas, M.K., Pearl, D.L., Shirley, J., Indigenous Health 830 Adaptation to Climate Change Research Group, Rigolet Inuit Community Government, McEwen, S.A., 831 2015. Acute gastrointestinal illness in two Inuit communities: burden of gastrointestinal illness in 832 Rigolet and Iqaluit, Canada. Epidemiol. Infect. 2015, 1-16. 833 
834 Hastings, E., Yasui, Y., Hanington, P., Goodman, K., CANHelp Working Group, 2014. Community-

835 driven research on environmental sources of $H$. pylori infection in arctic Canada. Gut Microbes 5(5), 836 606-617. http://doi.org/10.4161/19490976.2014.969639.

837

838 Hayward, J.L., Jackson, A.J., Yost, C.K., Truelstrup Hansen, L., Jamieson, R.C., 2018. Fate of 839 antibiotic resistance genes in two Arctic tundra wetlands impacted by municipal wastewater. Sci. Total 840 Environ. 642, 1415-1428.

841

842 Hayward, J.L., Jamieson, R.C., Boutilier, L., Goulden, T., Lam, B., 2014. Treatment performance 843 assessment and hydrological characterization of an arctic tundra wetland receiving primary treated 844 municipal wastewater. Ecol Eng 73, 786-797.

846 Health Canada, 2007. Eating well with Canada’s Food Guide - First Nations, Inuit and Métis. 847 Publication No. 3426 Cat. H34-159/2007E-PDF. ISBN: 978-0-662-45521-9. Ottawa, Canada:p.3 848 Retrieved from. http://publications.gc.ca/site/eng/9.650446/publication.html, Accessed date: 5 849 September 2018.

850

851 Heaney, C.D., Sams, E., Dufour, A.P., Brenner, K.P., Haugland, R.A., Chern, E., Wing, S., Marshall, 852 S., Love, D.C., Serre, M., Noble, R., Water, T.J., 2012. Fecal indicators in sand, sand contact, and risk 853 of enteric illness among beachgoers. Epidemiology 23, 95-106.

854

855 Heinke, G., Smith, D., Finch, G., 1991. Guidelines for the planning and design of wastewater lagoon 856 systems in cold climates. Can. J. Civil Eng. 18(4), 556-567. doi. http://dx.doi.org/10.1139/191-068. 857 
858 Hennessy, T., Bressler, J., 2016. Improving health in the Arctic region through safe and affordable 859 access to household running water and sewer services: an Arctic Council initiative. Int. J. Circumpol. 860 Heal. 75, 31149.

861

862 Holeton, C., Chambers, P.A., Grace, L., 2011. Wastewater release and its impact on Canadian waters. 863 Can. J. Fish. Aquat. Sci., 68, 1836-1869.

864

865 Howard, G., Pedley, S., Tibetemwa, S., 2006. Quantitative microbial risk assessment to estimate the 866 health risks attributable to water supply: can the technique be applied in developing countries with 867 limited data? J. Water Health 4(1), 49-65.

868

869 Huang, Y., Truelstrup Hansen, L., Ragush, C., Jamieson, R., 2017. Disinfection and removal of human 870 pathogenic bacteria in arctic waste stabilization ponds. Environ. Sci. Pollut. R. https://doi.org/10.1007/s 871 11356-017-8816-9.

872

873 Hunter, P.R., Zmirou-Navier, D., Hartemann, P., 2009. Estimating the impacts of health of poor 874 reliability of drinking water interventions in developing countries. Sci. Total Environ. 407, 2621-2624. 875

876 Hynds, P.D., Gill, L.W., Misstear, B.D., 2014. A quantitative risk assessment of Verotoxigenic E. coli 877 (VTEC) in private groundwater sources in the Republic of Ireland. Hum. Ecol. Risk Assess. 20, 14468781468.

879

880 IDEXX Laboratories Inc., 2013. Colilert-18 Test Kit Procedure. Westbrook, Maine, United States. 881 Retrieved from: https://www.idexx.com/resource-library/water/colilert-18-procedure-en.pdf. 
883 ITK (Inuit Tapiriit Kanatami), Johnson, K., 2008. National Inuit Position Paper Regarding the CCME 884 Canada-wide Strategy for the Management of Municipal Wastewater Effluent and Environment 885 Canada’s Proposed Regulatory Framework for Wastewater. Ottawa, Canada:p.27 Retrieved from. 886 https://www.itk.ca/inuit-management-municipal-wastewater/, Accessed date: 5 September 2018. 887

888 Iqbal, A., Goldfarb, D., Slinger, R., Dixon, B., 2015. Prevalence and molecular characterization of 889 Cryptosporidium spp. and Giardia duodenalis in diarrhoeic patients in the Qikitani Region, Nunavut, 890 Canada. Int. J. Circumpolar Health 74, 27713. http://dx.doi.org/10.3402/ijch.v74.27713. 891 892

Johnson, D.C., Enriquez, C.E., Pepper, I.L., Davis, T.L., Gerba, C.P., Rose, J.B., 1997. Survival of 893 Giardia, Cryptosporidium, Poliovirus and Salmonella in marine waters. Water Sci. Technol. 35(11-12), 894 261-268.

895

896 Johnson, K., Prosko, G., Lycon, D., 2014, September. The challenges with mechanical wastewater 897 systems in the Far North. Paper presented at the 2014 Annual Conference of Western Canada Water 898 and Waste Association, Regina, Canada.

899

900 Katukiza, A.Y., Ronteltap, M., van der Steen, P., Foppen, J.W.A., Lens, P.N.L., 2013. Quantification 901 of microbial risks to human health caused by waterborne viruses and bacteria in an urban slum. J. Appl. 902 Microbiol. 116, 447-463.

903

904 Knibbs, L., Sly, P., 2014. Indigenous health and environmental risk factors: an Australian problem with 905 global analogues? Glob. Health Action 7, 23766. http://dx.doi.org/10.3402/gha.v7.23766. 
907 Krumhansl, K., Krkosek, W., Greenwood, M., Ragush, C., Schmidt, J., Grant, J., Barrell, J., Lu, L., 908 Lam, B., Gagnon, G., Jamieson, R., 2015. Assessment of Arctic community wastewater impacts on 909 marine benthic invertebrates. Environ. Sci. Technol. 49(2), 760-766.

910

911 Leclerc, H., Schwartzbrod, L., Dei-Cas, E., 2002. Microbial agents associated with waterborne disease 912 Crit Rev Microbiol 28(4), 371-409.

913

914 Lévesque, B., Barthe, C., Dixon, B., Parrington, L., Martin, D., Doidge, B., Proulx, J.F., Murphy, D., 915 2010. Microbiological quality of blue mussels (Mytilus edulis) in Nunavik, Quebec: a pilot study. Can. 916 J. Microbiol. 56, 968-977.

917

918 Machdar, E., van der Steen, N.P., Raschid-Sally, L., Lens, P.N.L., 2013. Application of quantitative 919 microbial risk assessment to analyze the public health risk from poor drinking water quality in a low 920 income area in Accra, Ghana. Sci. Total Environ. 449, 134-142.

921

922 Manore, A., Shapiro, K., Sargeant, J., Weese, J.S., Cunsolo, A., Bunce, A., Shirley, J., Sudlovenick, E., 923 Harper, S.L., 2017, December. Cryptosporidium and Giardia in Clams in Iqaluit, Nunavut. ArcticNet 924 International Arctic Change Conference, Quebec, Canada.

925

926 Mathers, C.D., Stein, C., Ma Fat, D., Rao, C., Inoue, M., Tomijima, N., Bernard, C., Lopez, A.D., 927 Murray, C.J.L., 2002. Global Burden of Disease 2000, Version 2: Methods and Results. World Health 928 Organization, Geneva:p.108 Retrieved from. http://www.who.int/healthinfo/paper50.pdf, Accessed 929 date: 6 September 2018. 
931 McBride, G.B., Stott, R., Papps, D., Palliser, C., Jenner, G., Macdonald, G., 2012. Estimating health 932 risks to water users: marrying hydrodynamic models and risk models. Water Pract. Tech.. 7(4), 933 https://doi.org/10.2166/wpt.2012.078.

934

935 McBride, G.B., Stott, R., Miller, W., Bambic, D., Wuertz, S., 2013. Discharge-based QMRA for 936 estimation of public health risks from exposure to stormwater-borne pathogens in recreational waters in 937 the United States. Water Res. 47, 5282-5297.

938

939 McCullough, N.B., Eisele, C.W., 1951. Experimental human salmonellosis. II. Immunity studies 940 following experimental illness with Salmonella meleagridis and Salmonella anatum. J. Immunol. 941 66(5), 595-608.

942

McKeown, I., Orr, P., Macdonald, S., Kabani, A., Brown, R., Coghlan, G., Dawood, M., Embil, J., 944 Sargent, M., Smart, G., Bernstein, C., 1999. Helicobacter pylori in the Canadian arctic: Seroprevalence 945 and detection in community water samples. Am. J. Gastroenterol. 94(7), 1823-1829.

947 Messier, V., Lévesque, B., Proulx, J.F., Rochette, L., Serhir, B., Couillard, M., Ward, B.J., Libman, 948 M.D., Dewailly, É., 2012. Seroprevalence of seven zoonotic infections in Nunavik, Quebec, Canada. 949 Zoonoses Public Hlth. 59, 107-117.

950

951 Messner, M.J., Chappell, C.L., Okhuysen, P.C., 2001. Risk assessment for Cryptosporidium: a 952 hierarchical Bayesian analysis of human dose response data. Water Res. 35(16), 3934-3940. 953 
954 Moya, J., 2004. Overview of fish consumption rates in the United States. Hum. Ecol. Risk Assess. 10, $955 \quad 1195-1211$.

956

957 Neudorf, K., Huang, Y., Ragush, C., Yost, C., Jamieson, R., Truelstrup Hansen, L., 2017. Antibiotic 958 resistance genes in municipal wastewater treatment systems and receiving waters in Arctic Canada. Sci. 959 Total Environ. 598, 1085-1094.

960

961 Nevers, M.B., Boehm, A.B., 2011. Modeling fate and transport of fecal bacteria in surface water, in:

962 Sadowsky, M.J., Whitman, R.L. (Eds.), The fecal bacteria. American Society for Microbiology, 963 Washington, pp 165-187.

964

965 Nilsson, L.M., Destouni, G., Berner, J., Dudarev, A.A., Mulvad, G., Oland, J.Ø., Parkinson, A., 966 Tikhonov, C., Rautio, A., Evengård, B., 2013. A call for urgent monitoring of food and water security 967 based on relevant indicators for the Arctic. Ambio 42, 816-822.

968

969 Noble, R., Lee, I., Schiff, K., 2004. Inactivation of indicator microorganism from various sources of 970 faecal contamination in seawater and freshwater. J. Appl. Microbiol. 96(3), 464-472.

971

972 Nunavut Water Board, 2015. Public registry - annual municipal reports. http://www.nwb-oen.ca/conten 973 t/public-registry (accessed 15 February 2018).

974

975 Pardhan-Ali, A., Wilson, J., Edge, V.L., Furgal, C., Reid-Smith, R., Santos, M., McEwen, S.A., 2013.

976 Community-level risk factors for notifiable gastrointestinal illness in the Northwest Territories, 977 Canada, 1991-2008. BMC Public Health 13,63. https://doi.org/10.1186/1471-2458-13-63. 
979 Pardhan-Ali, A., Berke, O., Wilson, J., Edge, V.L., Furgal, C., Reid-Smith, R., Santos, M., McEwen, 980 S.A., 2012a. A spatial and temporal analysis of notifiable gastrointestinal illness in the Northwest 981 Territories, Canada, 1991-2008. Int. J. Health Geogr. 11:17. https://doi.org/10.1186/1476-072X-11-17. 982

983 Pardhan-Ali, A., Wilson, J., Edge,V.L., Furgal, C., Reid-Smith, R., Santos, M., McEwen, S.A., 2012 b. 984 A descriptive analysis of notifiable gastrointestinal illness in the Northwest Territories, Canada, 1991985 2008. BMJ Open 2:e000732. http://dx.doi.org/10.1136/bmjopen-2011-000732.

986

987 Parkinson, A.J., Evengard, B., Semenza, J.C., Odgen, N., Børensen, M.L., Berner, J., Brubaker, M., 988 Sjöstedt, A., Evander, M., Hondula, D.M., Menne, B., Pshenichnaya, N., Gounder, P., Larose, T., 989 Revich, B., Hueffer, K., Albihn, A., 2014. Climate change and infectious diseases in the Arctic: 990 establishment of a circumpolar working group. Int. J. Circumpol. Heal. 73:25163.

991

992

Ragush, C., Schmidt, J., Krkosek, W., Gagnon, G., Truelstrup Hansen, L., Jamieson, R., 2015.

993

Performance of municipal waste stabilization ponds in the Canadian Arctic. Ecol. Eng. 83, 413-421.

994

995

Rendtorff, R.C., 1954. The experimental transmission of human intestinal protozoan parasites: II.

996 Giardia lamblia cysts given in capsules. Am. J. Epidemiol. 59(2), 209-220. https://doi.org/10.1093/oxf 997 ordjournals.aje.a119634.

998

999 Sales-Ortells, H., Medema, G., 2014. Screening-level microbial risk assessment of urban water 1000 locations: a tool for prioritization. Environ Sci Technol 48, 9780-9789. 
1002 Schmidt, J., Ragush, C., Krkosek, W., Gagnon, G., Jamieson, R., 2016. Characterizing phosphorus

1003 removal in passive waste stabilization ponds in Arctic communities. Arctic Science 2, 1-14. https://doi. 1004 org/10.1139/as-2015-0002.

1005

1006 Schoen, M., Ashbolt, N., 2010. Assessing pathogen risk to swimmers at non-sewage impacted 1007 recreational beaches. Environ. Sci. Technol. 44, 2286-2291.

1008

1009 Shere, J.A., Kaspar, C.W., Bartlett, K.J., Linden, S.E., Norell, B., Francey, S., Schaefer, D.M., 2002.

1010 Shedding of Escherichia coli O157:H7 in dairy cattle housed in confined environment following

1011 waterborne inoculation. Appl. Environ. Microbiol. 68, 1947-1954.

1012

1013 Soller, J., Embrey, M., Tuhela, L., Ichida, A., Rosen, J., 2010. Risk-based evaluation of Escherichia

1014 coli monitoring data from undisinfected drinking water. J. Environ. Manage. 91, 2329-2335.

1015

1016 Sokolova, E., Petterson, S.R., Dienus, O., Nyström, F., Lindgren, P.E., Pettersson, T.J., 2015.

1017 Microbial risk assessment of drinking water based on hydrodynamic modelling of pathogen

1018 concentrations in source water. Sci Total Environ. 526, 177-186.

1019

1020 Statistics Canada, 2016. Population and dwelling counts. http://www12.statcan.gc.ca/census-

1021 recensement/2016/dp-pd/hlt-fst/pd-pl/index-eng.cfm (accessed 15 February 2018).

1022

1023 Stetler, R.E., Waltrip, S.C., Hurst, C.J., 1992. Virus removal and recovery in the drinking water 1024 treatment train. Water Res. 26, 727-731.

1025 
1026 Suk, W., Avakian, M., Carpenter, D., Groopman, J., Scammell, M., Wild, C., 2004. Human exposure

1027 monitoring and evaluation in the Arctic: The importance of understanding exposures to the

1028 development of public health policy. Environ. Health Persp. 112(2), 113-120.

1029

1030 Thivierge, K., Iqbal, A., Dixon, B., Dion, R., Lévesque, B., Cantin, P., Cédilotte, L., Ndao, M., Proulx, 1031 J., Yansouni, C., 2016. Cryptosporidium hominis is a newly recognized pathogen in the Arctic Region 1032 of Nunavik, Canada: Molecular characterization of an outbreak. PLoS Negl. Trop. Dis. 10(4), 1033 e0004534. https://doi.org/10.1371/journal.pntd.0004534.

1034

1035 Thomas, M.K., Murray, R., Flockhart, L., Pintar, K., Pollari, F., Fazil, A., Nesbitt, A., Marshall, B., 1036 2013. Estimates of the burden of food-borne illness in Canada for 30 specified pathogens and 1037 unspecified agents, circa 2006. Foodborne Path. Dis. 10, 639-648.

1038

1039

1040

USEPA (United States Environmental Protection Agency), 2012. Human health risk assessment. https://www.epa.gov/risk/human-health-risk-assessment (accessed 5 September 2018). 1041

1042 Waltner-Toews, D., Kay, J., Neudoerffer, C., Gitau, T., 2003. Perspective changes everything: 1043 managing ecosystems from the inside out. Front Ecol. Environ. 1(1), 23-30.

1045 Ward, R.L., Bernstein, D.I., Young, E.C., Sherwood, J.R., Knowlton, D.R., Schiff, G.M., 1986. Human 1046 rotavirus studies in volunteers: determination of infectious dose and serological response to infection. J. 1047 Infect. Dis. 154, 5(1), 871-880. https://doi.org/10.1093/infdis/154.5.871. 
1049 Westrell, T., 2004. Microbial Risk Assessment and its Implications for Risk Management in Urban 1050 Water Systems, ISBN 91-85295-98-1, Ph.D thesis, Linköping University, Linköping, Sweden. 1051

1052 WHO (World Health Organization), 2006. Guidelines for the Safe Use of Wastewater, Excreta and 1053 Greywater. Vol. 2. Wastewater Use in Agriculture. Geneva:p.222 Retrieved from. http://www.who.int/ 1054 water_sanitation_health/wastewater/gsuweg2/en/, Accessed date: 5 September 2018. 1055 1056 WHO (World Health Organization), 2016. Quantitative Microbial Risk Assessment: Application for 1057 Water Safety Management. Geneva:p.208 Retrieved from.http://www.who.int/water_sanitation_health 1058 /publications/qmra/en/, Accessed date: 5 September 2018. 1059

1060 Yansouni, C., Pernica, J., Goldfarb, D., 2016. Enteric parasites in Arctic communities: tip of the 1061 iceberg? Trends Parasitol. 32(11), 834-838.

1062

1063 Yapo, R.I., Koné, B., Bonfoh, B., Cissé, G., Zinsstag, J., Nguyen-Viet, H., 2014. Quantitative 1064 microbial risk assessment related to urban wastewater and lagoon water reuse in Abidjan, Côte 1065 d’Ivoire. J. Water Health 12(2), 301-309. https://doi.org/10.2166/wh.2013.051. 1066

1067 Yates, C., Wootton, B., Murphy, S., 2012. Performance assessment of arctic tundra municipal 1068 wastewater treatment wetlands through an arctic summer. Ecol. Eng. 44, 160-173. 
